\title{
Cooperation of upper and lower boundary-layer fractionations in a sheet-like intrusion: Composition and microstructure of the Aosawa dolerite sill in Yamagata Prefecture, northeastern Japan
}

\author{
Yushi TAKADA ${ }^{* * *}$ and Kazuhito OZAWA ${ }^{*}$ \\ "Department of Earth and Planetary Science, Graduate School of Science, The University of Tokyo, \\ Hongo 7-3-1, Bunkyo-ku, Tokyo 113-0033, Japan \\ ${ }^{* *}$ Present address: Sumitomo Metal Industries, LTD. Steel Sheet Products Development Section, \\ Kashima Steel Works 3, Hikari, Kashima, Ibaraki 314-0014, Japan
}

\begin{abstract}
Homogeneous fractionation, involving crystal nucleation, growth, and separation from a melt-dominant mag$\mathrm{ma}$, and boundary-layer fractionation, involving the separation of a fractionated interstitial melt from a crystaldominant boundary layer and its mixing with the main magma body, have been advocated as two major differentiation mechanisms in a crustal magma chamber. In this study, we focus on one of the dolerite sills in the Aosawa area, Yamagata Prefecture, Japan, to elucidate the roles of the two mechanisms in the differentiation of a sheet-like magma body. The intrusion is concordantly intruded into black mudstone and is $\sim 100 \mathrm{~m}$ thick and more than $5 \mathrm{~km}$ in lateral extension. The chilled margins contain olivine (5.3 vol\%) and plagioclase (1.9 vol\%) as phenocrysts. There is an absence of clinopyroxene in the chilled margins, and there are systematic sill-scale variations in the whole-rock major- and trace-element contents that require the addition or removal of clinopyroxene. These findings suggest sill-scale differentiation, involving the transportation of crystals that nucleated and grew in the sill, and/or the transfer of the residual melt. The downward increases in mode and size of clinopyroxene and in the size of the most dominant plagioclase, all with maxima near the bottom, and the occurrence of pigeonite rimming augite only near the bottom, suggest a slower cooling rate in the lower boundary layer compared to the upper one. Clinopyroxene crystals with $\mathrm{Cr}$-rich cores that show textures suggesting rapid growth, such as remarkable sector zoning, melt inclusions, and small euhedral plagioclase, are more abundant at 5-15 $\mathrm{m}$ above the lower contact. These observations lead us to believe that clinopyroxene nucleated and grew near the upper boundary layer, where large supersaturation occurred, and then settled to concentrate in the lower boundary layer, where slower cooling provided suitable conditions for pigeonite crystallization. The upward increase in the incompatible elements and the decrease in compatible elements from the zone containing a high concentration of Cr-rich clinopyroxene suggest that a fractionated melt, which was formed through enhanced overgrowth on settled clinopyroxene, was transported upwards. The sill-scale magmatic differentiation in the Aosawa dolerite intrusion took place through crystal settling from the roof boundary layer, followed by the upward transportation of the fractionated melt from the bottom boundary layer. The lower-boundary-layer fractionation was probably very effective because the settling of the crystals thickened the bottom boundary layer to facilitate an effective melt-crystal separation.
\end{abstract}

Keywords: Magma-fractionation mechanisms, Homogeneous fractionation, Boundary-layer fractionation, Aosawa dolerite sill

\section{INTRODUCTION}

Magmas generated in the mantle are transported to the Earth's surface where they promote crustal growth and af-

doi:10.2465/jmps.100306

Y.Takada,ytakada3012@yahoo.co.jp Corresponding author fect the Earth's surface environment. On their way to the surface, the magmas cool, and their chemical composition is changed by various processes such as crystallization differentiation, magma mixing, and assimilation of crustal materials, enhancing the chemical diversity of the crust. It is important to understand the mechanisms of crustal dif- 
ferentiation that govern the extent and time scale of the evolution of the chemical composition of the crust. Various geophysical evidence for the existence of magma chambers, which could be a major site for magmatic differentiation in the crust, has been reported from a variety of tectonic settings such as island-arcs, mid ocean-ridges, and oceanic intraplate volcanic islands (Lee and Ukawa, 1992; Sinton and Detrick, 1992; Haslinger et al., 2001).

Homogeneous fractionation, involving the separation of crystals nucleated and grown in the main magma body of a crustal magma chamber, and boundary-layer fractionation, involving compositional convection induced by crystal growth in the cooler marginal zone, are thought to be the most important differentiation mechanisms (e.g., Jaupart and Tait, 1995; Marsh, 1996). These contrasting differentiation processes may or may not be related to mechanisms of heat transfer, that is, thermal convection and thermal conduction (Kuritani, 2007). Heat transport is strongly affected by phase transitions and material transport in the magma chamber. However, it is still not clear which differentiation mechanism actually occurs and how the choice of mechanism is related to the composition of the magma and the depth, dimension, and shape of the magma chambers. Previously, Kuritani (2009) showed the importance of water content and pressure in this choice. This issue can be addressed by combining theoretical modeling and observation on a geometrically simple sheet-like intrusion that records temporal changes in the physical and chemical conditions of the magma system as sequential changes of composition and microstructure from the chilled margins to the last frozen zone.

Marsh (1996) argued that most sheet-like intrusions, even if they are $\sim 200 \mathrm{~m}$ thick, are solidified without magmatic differentiation because of the suppression of thermal convection, a stable upper solidification front, and the fast growth of the bottom boundary layer impeding compositional convection. Using the example of the notable magmatic fractionation in the 120-m-thick Nosappumisaki intrusion in Hokkaido, Japan, Simura and Ozawa (2011) argued that the presence of a thick bottom accumulation zone is critical to induce compositional convection. There are, however, several reports that advocate insitu differentiation by crystal growth in a sheet-like intrusion without an initial bottom crystal pile (e.g., Kerr and Tait, 1986; Scoon and Mitchell, 1994; Tait and Jaupart, 1992; Jellinek and Kerr, 2001). The aim of this study is to examine the interplay between the upper- and lowerboundary-layer fractionations based on detailed chemical and textural observations of a sheet-like intrusion in the Aosawa area, Yamagata Prefecture, Japan.

\section{GEOLOGICAL SETTING OF THE AOSAWA DOLERITE}

The dolerite sills in the Aosawa area, Sakata City, Yamagata Prefecture, northeastern Japan, are a group of sheetlike intrusions, $10-100 \mathrm{~m}$ in thickness (Fig. 1). These intrusions will be referred to as the Aosawa dolerite sills in this paper in accordance with previous works (Fujii, 1972, 1974a). These sills are concordantly intruded into the Miocene sedimentary rocks, mostly black mudstone, which form an anticline with the NS trending fold axis [Aosawa anticlinorium (Tsuchiya, 1989b); Fig. 1]. The volcanic activity that produced the dolerite was a series of basaltic magmatic events in a back-arc region of northern Japan in the middle Miocene. The tectonic transition in the back arc of northern Japan in the middle Miocene started with the formation of horsts and grabens in the early Miocene, followed by active basaltic volcanism on the sea floor of the Japan Sea. The Aosawa dolerite, which dates to $10.4 \pm 0.3 \mathrm{Ma}$, using the $\mathrm{K}-\mathrm{Ar}$ method (Ohki et al., 1995), is one of the products of this volcanism along the rift zone in the latest stage in the spreading of the Japan Sea (Sato, 1986; Tsuchiya, 1989a). At that time, the stress field had a horizontal maximum compression ori-

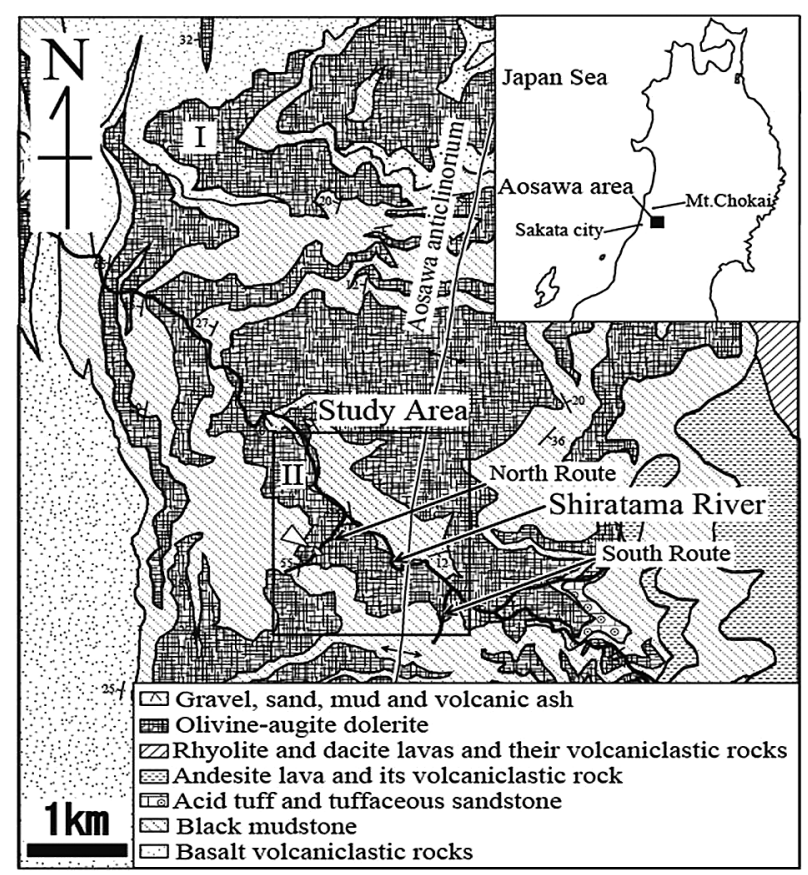

Figure 1. Geological map of the Aosawa area, Yamagata Prefecture, northeastern Japan, modified from Tsuchiya (1989b). Aosawa dolerite I was studied by Fujii (1972), and Aosawa dolerite II is the target of our study. The field survey was made along two tributaries of Shiratama River, indicated as the north and south routes. An interval of sedimentary rock (shown as a white ellipse) was encountered near the upper contact in the north route, as indicated by the white arrowhead. 
ented along NE-SW (Amano and Sato, 1958).

Fujii (1972, 1974a, 1974b) investigated a dolerite intrusion at the fold axis with a thickness of $80 \mathrm{~m}$. He found an olivine-rich layer (picritic layer) and identified four lithologies in the sill: olivine basalt, olivine dolerite, pegmatitic dolerite, and picritic dolerite. In his analysis, the modal abundance of olivine is almost constant in the upper two thirds; but, going downwards, it increases rapidly to a height of $20 \mathrm{~m}$ from the bottom, followed by a decrease toward the lower chilled margin. The vertical modal variation of plagioclase and clinopyroxene does not display any systematic trends. On the basis of the phenocryst abundance in the lower chilled margin, the amounts of phenocrysts in the intruded magma were estimated to be $6.9 \mathrm{vol} \%$ for olivine and $19.1 \mathrm{vol} \%$ for plagioclase. Fujii (1974b) argued that olivine crystals were present before the intrusion and that the crystals had settled with negligible nucleation and growth. He applied a simple model of crystal settling to reproduce the observed variation in the olivine mode. In spite of the notable variation in the olivine mode, the whole-rock chemical composition in the sill shows insignificant variation, with weak maxima for $\mathrm{FeO}$ and $\mathrm{MgO}$ content at the horizon of the picritic dolerite (Fujii, 1974a).

The intrusion being investigated in this study is called Aosawa dolerite II, to distinguish it from the dolerite sill studied by Fujii (1972, 1974a), which hereafter will be referred to as Aosawa dolerite I. Aosawa dolerite II is concordantly intruded into black mudstone and is distributed to the west of the Shiratama River, which runs NW-SE (Fig. 1). The dolerite strikes NW-SE and dips $\mathrm{SW}$ in the western wing of the Aosawa anticlinorium, and is one of the most planar intrusions in the Aosawa dolerite. This is in contrast to Aosawa dolerite I, which shows irregular distribution, owing to its occurrence along the fold axis (Fig. 1). Aosawa dolerite II is approximately 100 $\mathrm{m}$ thick and extends more than $5 \mathrm{~km}$ along the strike. The stratigraphic relationship between Aosawa dolerites I and II is not clear.

A geological map of the surveyed area (Tsuchiya, 1989b) is shown in Figure 1. Rocks were collected from the lower contact to the upper contact of the sill along the two tributaries of Shiratama River, both of which run nearly perpendicular to the strikes of the intrusion (Fig. 1). The upper contact with the host sedimentary rocks was observed in the northern route. The contact strikes $\mathrm{N} 15^{\circ} \mathrm{W}$ and dips $25^{\circ} \mathrm{W}$, and is planner at the outcrop scale $(\sim 10$ $\mathrm{m})$. At the contact, a chilled margin can be observed. Both the lower and upper contacts of the sill were observed in the southern route. Platy joints, sub-parallel to the contacts with the host rocks, are locally developed. No distinct lithological variation was noticed during the field observation, except for the chilled margin rocks. Near the upper contact in the northern river, there is an intercalation of sedimentary rocks with a thickness of $\sim 5 \mathrm{~m}$ (the white ellipse indicated by a triangle in Fig. 1). A finegrained basalt was observed at the lower contact with the sedimentary rock, the groundmass of which is much more crystalline and larger in grain size than the chilled margins at the roof. Near the upper contact in the southern route, leucocratic rocks with pipe-like morphology were observed. Such leucocratic rocks are also present near the lower contact in the southern route. There is no evidence for partial melting in the host mudstone at the contacts, or even in the sedimentary intercalation in the northern route.

\section{ANALYTICAL METHODS}

Whole-rock major- and trace-element contents were determined by a PANalytical Axios XRF system at the Department of Earth and Planetary Science of the University of Tokyo, according to the analytical procedure described by Kushiro (1994). Samples are somewhat altered, but this alteration was limited to the replacement of olivine and interstitial glass by clay minerals. Samples from the northern route were analyzed both for major and trace elements, but those from the southern route were analyzed only for trace elements.

The mineral compositions of samples from the northern route were determined by electron probe microanalyzer, using a JEOL JXA-8900L, at the Department of Earth and Planetary Science of the University of Tokyo. The analytical procedures are similar to those of Nakamura and Kushiro (1970) with the correction procedure of Bence and Albee (1968). The analyses were conducted using an acceleration voltage of $15 \mathrm{kV}$, a beam current of $12 \mathrm{nA}$ on a Faraday cup, and $10 \mathrm{~s}$ counting time for plagioclase and $40 \mathrm{~s}$ counting time for other minerals. Because of the development of sector zoning in clinopyroxene, several line profiles were taken for each grain, followed by observation with BEI to pick up appropriate core data. Core data was identified as the center of symmetry of a line profile, irrespective of single or double peaks. In the map analysis, the specimen stage was automatically driven and 10-70 ms counting time was used at each point with a pixel size of 1-40 $\mu \mathrm{m}$. The total number of pixels for each map analysis ranged from $200 \times 350$ to $1000 \times 1000$.

The modal abundance and size distribution of the crystals in the northern route were determined by area measurement on digital images of thin sections $(1 \times 1.2$ $\mathrm{cm})$. Digital images were imported with a resolution of $2272 \times 1704$ pixels; the constituent minerals were identi- 
fied under an optical microscope, and the outlines of the crystals were traced. The area, length, and width of each crystal were determined using Image $J$, a particle-analysis application. The modal abundance of clinopyroxene for the northern route was measured by tracing all the crystals. The modal abundances of plagioclase and olivine measuring more than $1.0 \mathrm{~mm}$ and $0.5 \mathrm{~mm}$ across, respectively, were also measured. The alteration products of olivine and glass are very similar under an optical microscope, but large pseudomorphs of olivine phenocrysts can be distinguished by their euhedral to subhedral outline. Using Image $\mathrm{J}$, the modes of $\mathrm{Cr}$-rich and $\mathrm{Cr}$-poor clinopyroxenes were measured by counting the number of pixels of each X-ray strength after dividing them into two, using an appropriate threshold.

\section{LITHOLOGICAL VARIATION IN AOSAWA DOLERITE II}

\section{Rock texture}

The rocks of Aosawa dolerite II from the northern and southern routes are composed of plagioclase, clinopyroxene (augite and pigeonite), olivine, magnetite, and glass including acicular crystals of plagioclase, augite, and $\mathrm{Fe}-$ Ti oxides. The chilled margins contain olivine (5.3 vol\%) and plagioclase (1.9 vol\%) phenocrysts with a groundmass consisting of plagioclase, augite, olivine, and glass. Olivine and glass are totally or partially altered into either clay minerals or carbonate. Clinopyroxene phenocrysts are absent in the chilled margin rocks, and no vesicle is observed anywhere in the sill. The modal abundances of phenocrysts are lower, particularly for plagioclase, compared to those reported by Fujii (1972) for Aosawa dolerite I. The olivine phenocrysts are $0.5-2.0 \mathrm{~mm}$ in size, and the plagioclase phenocrysts $1.0-2.2 \mathrm{~mm}$. Such large euhedral to subhedral olivine and plagioclase crystals are also present inside the sill, giving rise to bimodal size distributions. From here on, they are referred to as "phenocrysts." The surrounding part of the phenocrysts contains olivine and plagioclase with smaller grain sizes, and will hereafter be referred to as the "matrix." The matrix consists of clinopyroxene, olivine, plagioclase, magnetite, and glass with acicular plagioclase and augite crystals. Euhedral clinopyroxene phenocrysts $(0.4-0.6 \mathrm{~mm}$ in size) occur in a fine-grained matrix in the rocks within approximately $10 \mathrm{~cm}$ of the contact with the sedimentary intercalation at a height of $70 \mathrm{~m}$ from the bottom (Fig. 2).

Clinopyroxene occurring away from the contacts is grouped into two types: euhedral crystals that do not show an interlocking texture with plagioclase, and ophitic or subophitic crystals totally or partially containing euhedral

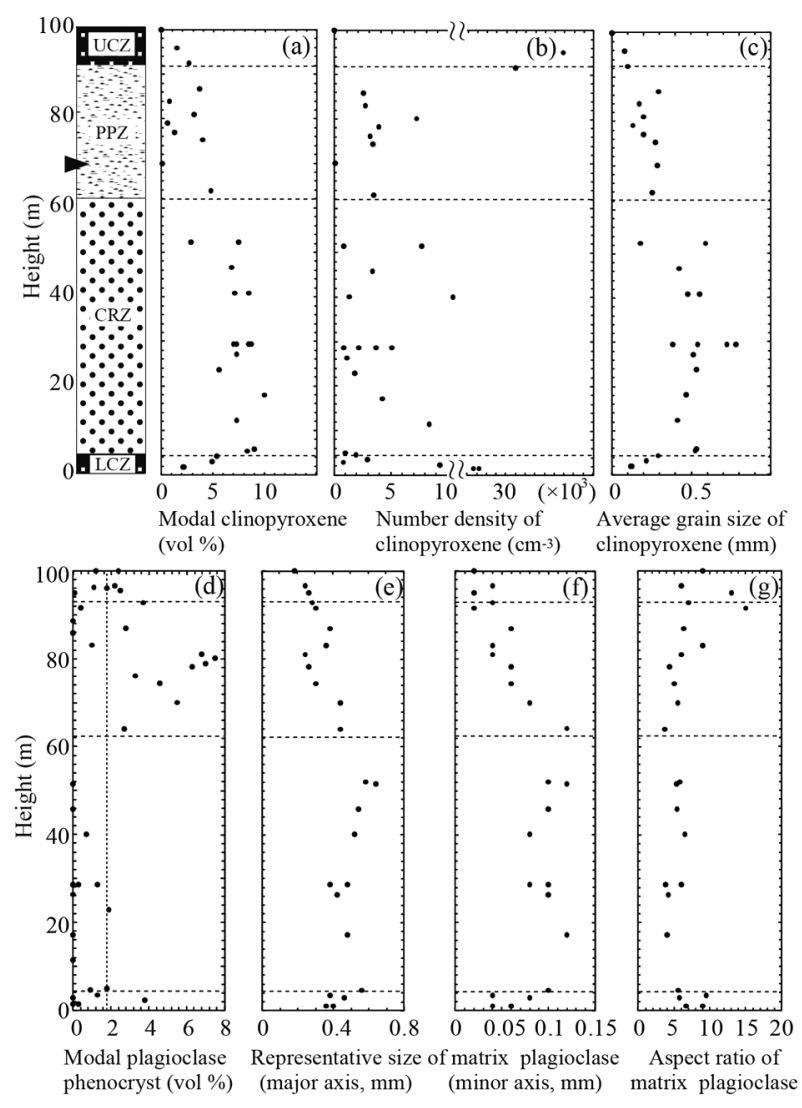

Figure 2. Vertical variations of modal abundance (vol\%) (a), number density (b), and average grain size (major axis) (c) of clinopyroxene; variations of modal abundance of plagioclase phenocryst (d); and length (e), width (f), and aspect ratio (g) of the most common matrix plagioclase occurring between olivine and plagioclase phenocrysts. In (d), the modes of plagioclase in the initial magma are shown by vertical dotted lines. The intrusion is divided into four lithological zones: upper chilled zone (UCZ), plagioclase-phyric zone (PPZ), clinopyroxene-rich zone (CRZ), and lower chilled zone (LCZ), as shown by the lithological column on the left-hand side. See Figure 5 and the text for more details. The solid right-pointing triangle on the left-hand side of the column indicates the 65-70 $\mathrm{m}$ height of the interval of sedimentary rock found in the north route.

laths of plagioclase. Sector and oscillatory zonings are often observed in both euhedral and ophitic clinopyroxenes. Moving downwards from the upper contact, the mode of clinopyroxene gradually increases and reaches its maximum near the lower contact, below which it sharply decreases to zero at the contact (Fig. 2a). The maximum is located in the interval 5-40 $\mathrm{m}$ from the bottom, where the mode is nearly constant. The number density of clinopyroxene increases markedly in the directions of both the upper and lower contacts with the host sedimentary rocks. It is scattered mostly through the interior of the intrusive body, but tends to be higher in the lower half (Fig. 2b). The average grain size varies from 0.1 to $0.8 \mathrm{~mm}$ and is larger in the lower half of the sill (Fig. 2). The size gradu- 
ally increases from the upper chilled margin and reaches a wide zone of maximum in the lower half of the sill, from where it rapidly decreases toward the lower contact. The clinopyroxene is either augite or, more rarely, pigeonite. Pigeonite appears mantling augite only in the lower chilled zone (Fig. 3), suggesting that the pigeonite crystallized following the crystallization of augite. Orthopyroxene was not found in any of the examined samples.

Figure 4 summarizes the morphological variation of

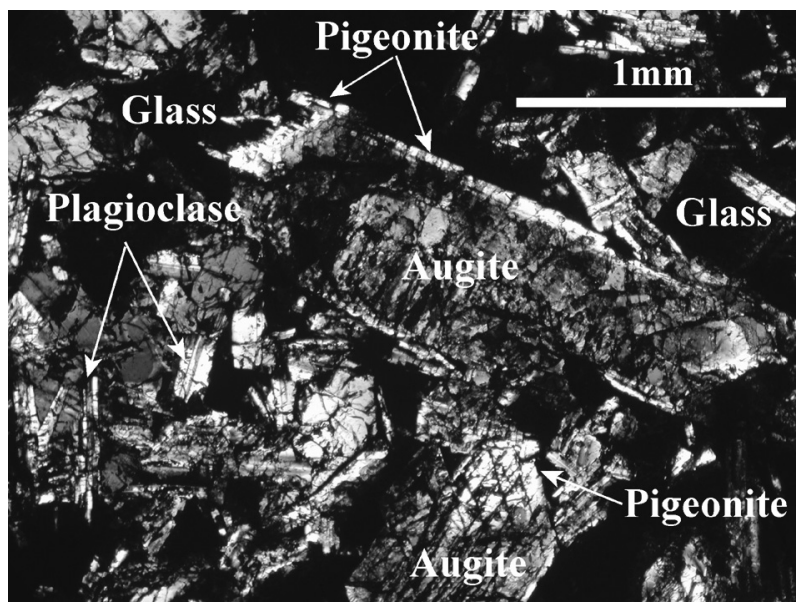

Figure 3. Photomicrograph (under crossed Nicols) of a rock sampled (\#07081308) near the bottom of Aosawa dolerite II, showing pigeonite rimming augite. (Color version of Figure 3 is available online from http://joi.jlc.jst.go.jp/JST.JSTAGE/jmps/100306.) clinopyroxene in Aosawa dolerite II. Some large clinopyroxene crystals, which occur in the lower part of the sill, are ophitic and are particularly developed at heights of 3-4 $\mathrm{m}$ from the bottom. They are not homogeneously distributed in a sample, and typically form a networked structure, as shown by the samples taken at $11.4 \mathrm{~m}, 28.6$ $\mathrm{m}$, and $40.1 \mathrm{~m}$ from the bottom (Fig. 4). Larger clinopyroxene crystals occurring at 5-52 $\mathrm{m}$ from the bottom are either euhedral or ophitic. Smaller clinopyroxene crystals occurring above $52 \mathrm{~m}$ are either euhedral or subophitic.

Olivine crystals, which mostly have been altered to clay minerals or, less frequently, to quartz accompanied by carbonate, are euhedral to subhedral. They are more abundant in the lower part than in the upper part $(\sim 10$ vol\%). The variation is very similar to that of the clinopyroxene mode. The average grain size of olivine is almost constant $(\sim 0.5 \mathrm{~mm})$ throughout the intrusion. Due to the alteration of olivine, which is very similar to that of interstitial altered glass, the olivine mode has a very large uncertainty and tends to be overestimated. This is not shown in Figure 2.

The mode of plagioclase phenocrysts is high at 75$85 \mathrm{~m}$ from the bottom, and decreases toward the upper contact (Fig. 2d). The number density and size of plagioclase phenocrysts show the same tendency. The mode of plagioclase phenocrysts has a weak peak at a height of 5-10 $\mathrm{m}$ from the bottom. Plagioclase phenocrysts often

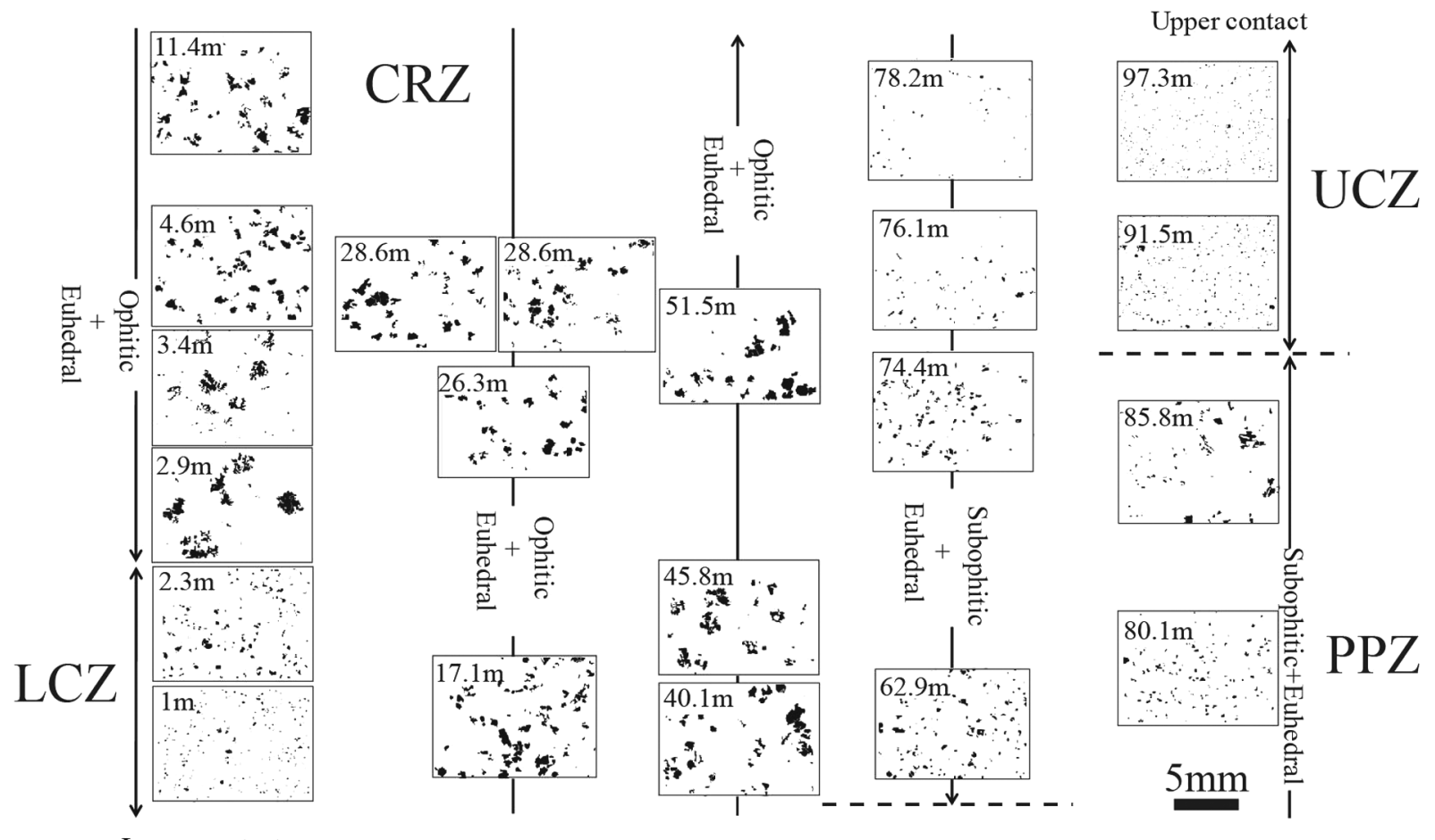

Lower contact

Figure 4. Morphological variation of clinopyroxene (black area) in Aosawa dolerite II. The lithological zones, LCZ, CRZ, PPZ, and UCZ, are defined in Figure 5. The height of each sample is shown in the upper-left corner of each drawing. 
form an aggregate exhibiting a glomeroporphyritic texture and are more abundant in the upper part. The size of matrix plagioclase increases going from the top to the bottom, except near the lower contact (Figs. 2e and 2f). The aspect ratio of matrix plagioclase is very high near the top and decreases downwards (Fig. 2g).

Magnetite is euhedral, subhedral, or dendritic and occurs in the matrix or in clinopyroxene. The grain size ranges from $0.01-0.1 \mathrm{~mm}$. The modal abundance increases from the top to $60 \mathrm{~m}$ from the bottom, and remains almost constant at $1 \mathrm{vol} \%$ below this height. Altered glass with elongated acicular crystals is interstitial to other minerals and is present throughout the intrusion. Although the modal abundance of glass is difficult to measure, because of its similarity to the alteration product of small olivine grains, it is unlikely that the abundance shows any systematic vertical variation.

According to the size, mode, number density, and morphology of clinopyroxene and plagioclase, the intrusion can be classified into four lithological zones (Fig. 5): upper chilled zone (UCZ), plagioclase-phyric zone (PPZ), clinopyroxene-rich zone (CRZ), and lower chilled zone (LCZ). In the upper and lower chilled zones, rocks are characterized by a porphyritic texture with groundmass (Figs. 5a and 5e). In the plagioclase-phyric zone, plagioclase shows a distinct bimodal size distribution and often forms aggregates (Fig. 5b). In this zone, clinopyroxene is either subophitic or euhedral and its maximum size is 0.7 $\mathrm{mm}$. In the clinopyroxene-rich zone, clinopyroxene is either ophitic or euhedral and has a maximum grain size of $1.6 \mathrm{~mm}$, except at the bottom of this zone, where clinopryroxene shows a remarkable ophitic texture, interlocking with finer plagioclase and often forming aggregates up to $4 \mathrm{~mm}$ across (Fig. 5d).

\section{Whole-rock chemical composition}

The whole-rock chemical compositions from Aosawa dolerite II are plotted against $\mathrm{SiO}_{2}$ content for major oxides, shown in Figure 6, and against $\mathrm{TiO}_{2}$ for trace elements, shown in Figure 7. The representative compositions are listed in Table 1. The $\mathrm{SiO}_{2}$ content varies from 49 to $54 \mathrm{wt} \%$. $\mathrm{TiO}_{2}, \mathrm{Na}_{2} \mathrm{O}, \mathrm{K}_{2} \mathrm{O}$, and $\mathrm{P}_{2} \mathrm{O}_{5}$ all show positive correlations, and $\mathrm{MnO}, \mathrm{MgO}, \mathrm{CaO}$, and $\mathrm{FeO}$ show negative correlations with $\mathrm{SiO}_{2}$. The $\mathrm{Al}_{2} \mathrm{O}_{3}$ content is nearly constant even though the $\mathrm{SiO}_{2}$ content varies by up to $5 \mathrm{wt} \%$. $\mathrm{TiO}_{2}$ is positively correlated with incompatible trace elements and incompatible major oxides $(\mathrm{Nb}, \mathrm{Ba}$, $\mathrm{Sr}, \mathrm{Zr}, \mathrm{Rb}, \mathrm{La}_{2} \mathrm{O}_{5}$, and $\mathrm{K}_{2} \mathrm{O}$ ) and shows negative correlations with compatible trace elements $(\mathrm{Cr}, \mathrm{Co}$, and $\mathrm{Ni})$. Similar correlations are also noticed even if other trace elements, such as $\mathrm{Nb}$, are used instead of $\mathrm{TiO}_{2}$. The $\mathrm{Nb}$

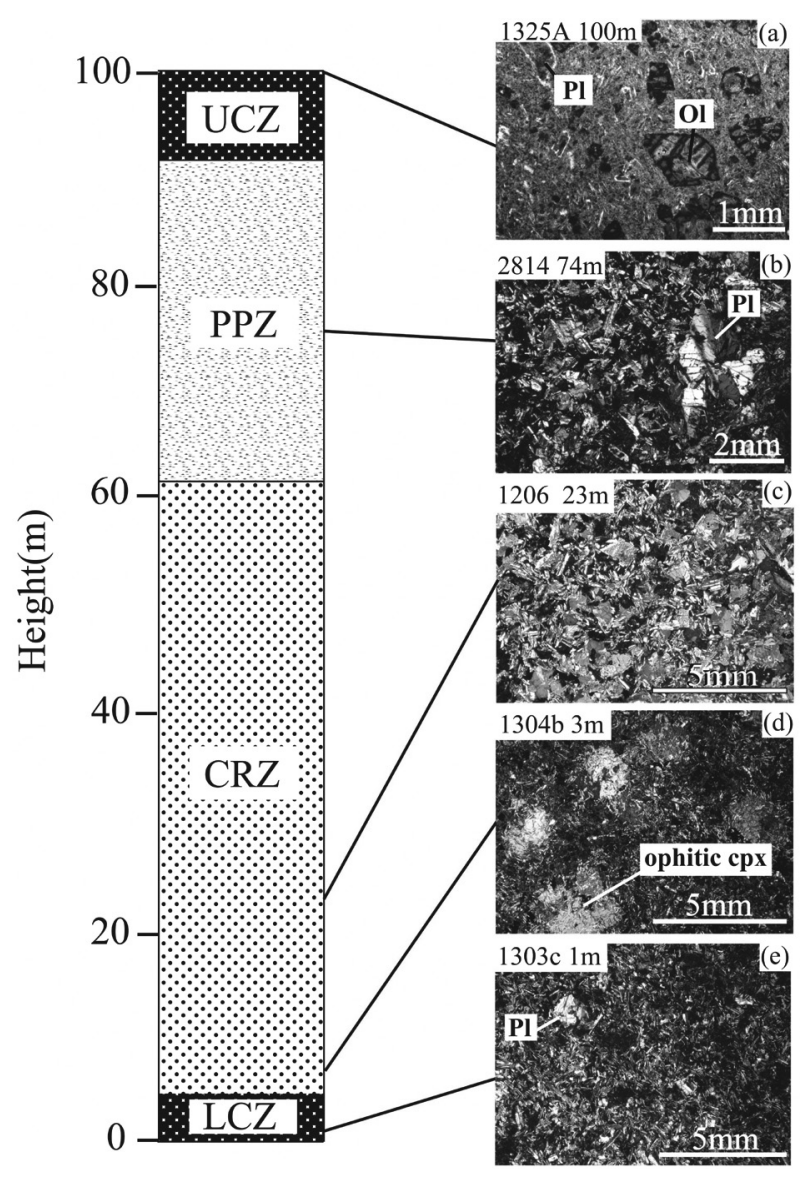

Figure 5. Lithological division of the Aosawa dolerite II (left column) based on phenocryst mode and texture. Abbreviations for lithological zone names are: UCZ, upper chilled zone; PPZ, plagioclase-phyric zone; CRZ, clinopyroxene-rich zone; LCZ, lower chilled zone. Representative photomicrographs for distinct lithologies are shown in the right column. In the upper-left corner of each photomicrograph, the height from the bottom of the intrusion is shown with a sample number. (a) Plagioclase and olivine phenocrysts set in glassy groundmass from the upper chilled zone. (b) Phenocrysts of plagioclase forming aggregate and olivine set in the finer matirx, including clinopyroxene and plagioclase, from the PPZ. Clinopyroxene is rare in this zone. (c) Subophitic clinopyroxene, euhedral olivine, and fine plagioclase from the CRZ. (d) Coarse ophitic clinopyroxene, forming an aggregate interlocking with finer plagioclase in the matrix, from the bottom of the CRZ. (e) Finer plagioclase and clinopyroxene forming groundmass with altered glass, and plagioclase phenocryst, from the LCZ. Photomicrographs (b), (c), (d), and (e) are under crossed Nicols, and (a) is under open Nicol. (Color version of Figure 5 is available online from http://joi.jlc.jst.go.jp/JST.JSTAGE/jmps/100306.)

content is positively correlated with incompatible elements $(\mathrm{Ba}, \mathrm{Sr}, \mathrm{Zr}, \mathrm{Rb}$, and $\mathrm{Y})$ and negatively correlated with compatible elements $(\mathrm{Cr}, \mathrm{Co}$, and $\mathrm{Ni})$.

\section{Stratigraphic variation of whole-rock chemical compositions}

Significant compositional variations at similar heights or 

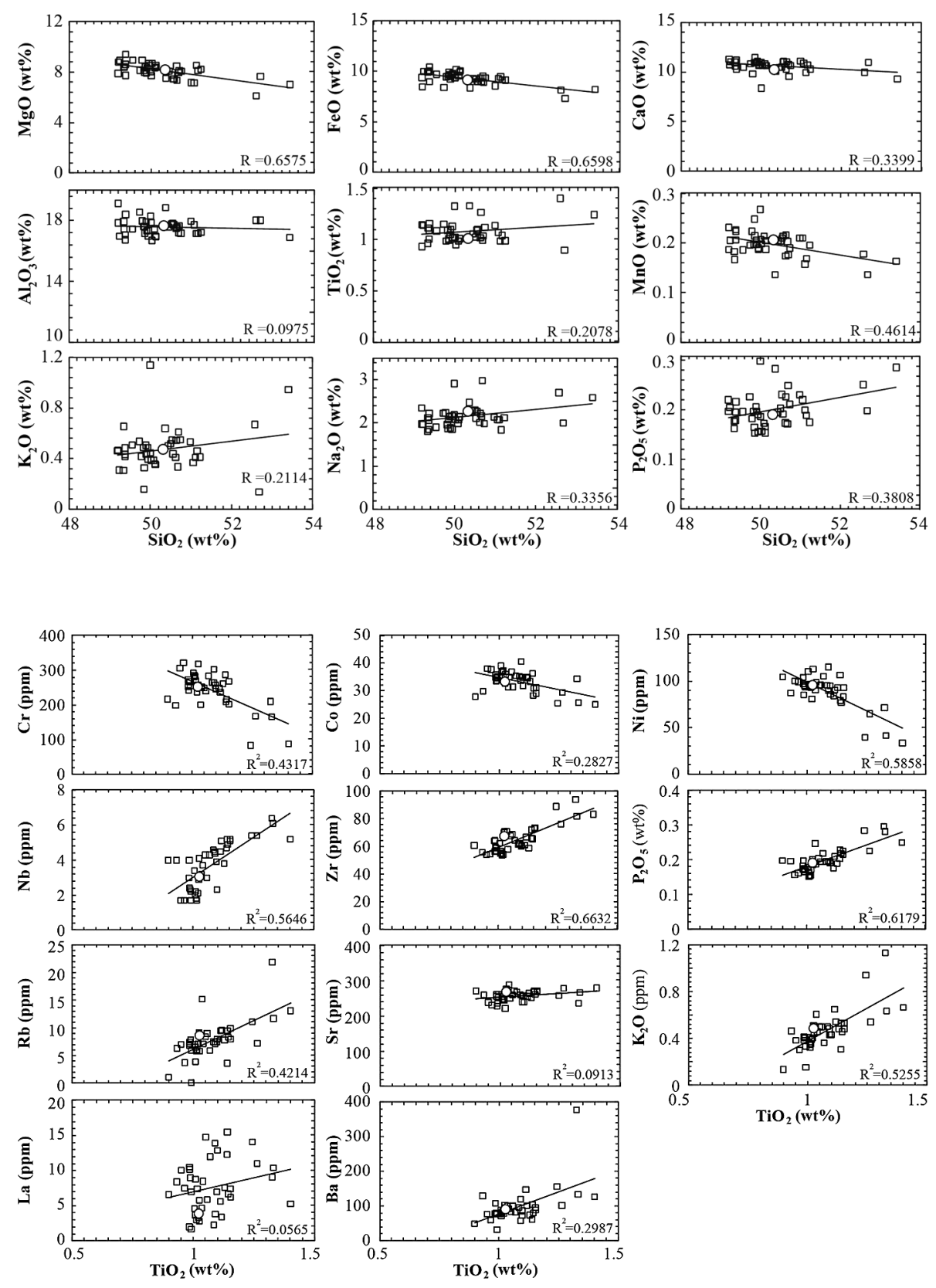

Figure 6. Harker variation diagrams for major oxides in rocks from Aosawa dolerite II, with a linear regression line. Estimated compositions of the initial magma are shown as circles. Correlation coefficients (R) are shown in each panel.
Figure 7. Trace-element contents and incompatible major oxide contents in rocks from Aosawa dolerite II plotted against $\mathrm{TiO}_{2}$ content, with a linear regression line. Estimated compositions of the initial magma are shown as circles. Correlation coefficients (R) are shown in each panel. even in the same outcrop (horizontal bars in Fig. 8) demonstrate that there is local-scale differentiation. In order to examine if there is any sill-scale compositional variation, the average at each outcrop was calculated and plotted against the height from the bottom (Fig. 8). The variations are significant and systematic, suggesting a sill-scale differentiation. The $\mathrm{K}_{2} \mathrm{O}, \mathrm{P}_{2} \mathrm{O}_{5}, \mathrm{Al}_{2} \mathrm{O}_{3}, \mathrm{TiO}_{2}$, and $\mathrm{Na}_{2} \mathrm{O}$ contents show approximately similar variation patterns (Fig. 8). The $\mathrm{FeO}$ and $\mathrm{MgO}$ contents show a different variation pattern, which is almost antithetic to those of $\mathrm{P}_{2} \mathrm{O}_{5}$ and other incompatible oxides. The $\mathrm{Sr}, \mathrm{Nb}, \mathrm{Rb}$, and $\mathrm{Zr}$ contents show variations similar to those of the major incompatible oxides, whereas the $\mathrm{Co}, \mathrm{Cr}$, and $\mathrm{Ni}$ contents show trends similar to those of the major compatible oxides (Fig. 8).

The contents of incompatible elements/oxides such as $\mathrm{K}_{2} \mathrm{O}, \mathrm{P}_{2} \mathrm{O}_{5}, \mathrm{TiO}_{2}, \mathrm{Al}_{2} \mathrm{O}_{3}, \mathrm{Rb}, \mathrm{Nb}, \mathrm{Zr}$, and $\mathrm{Sr}$, decrease slightly upwards in the lower chilled zone (0-3 m height). With further increases in height, these contents increase, with a maximum at $\sim 30 \mathrm{~m}$ in height in the clinopyroxene-rich zone, followed by a decrease (Fig. 8). The decrease in the incompatible elements from this height continues up to the center of the sill at $\sim 60 \mathrm{~m}$ from the bottom. After the central minimum, the contents increase up to $75 \mathrm{~m}$ in height, followed by a decrease, to give rise to a very sharp maximum in the plagioclase-phyric zone. 


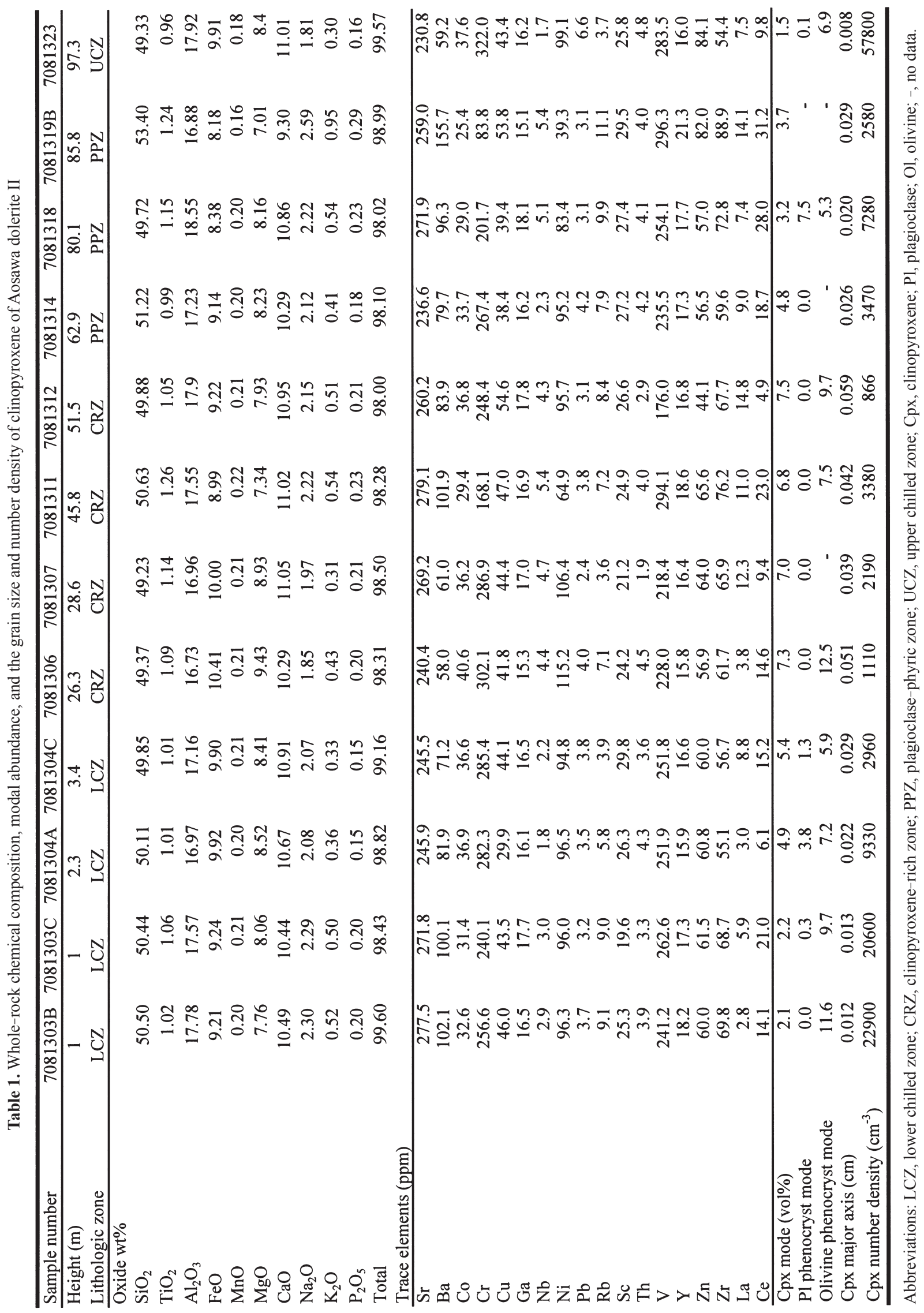



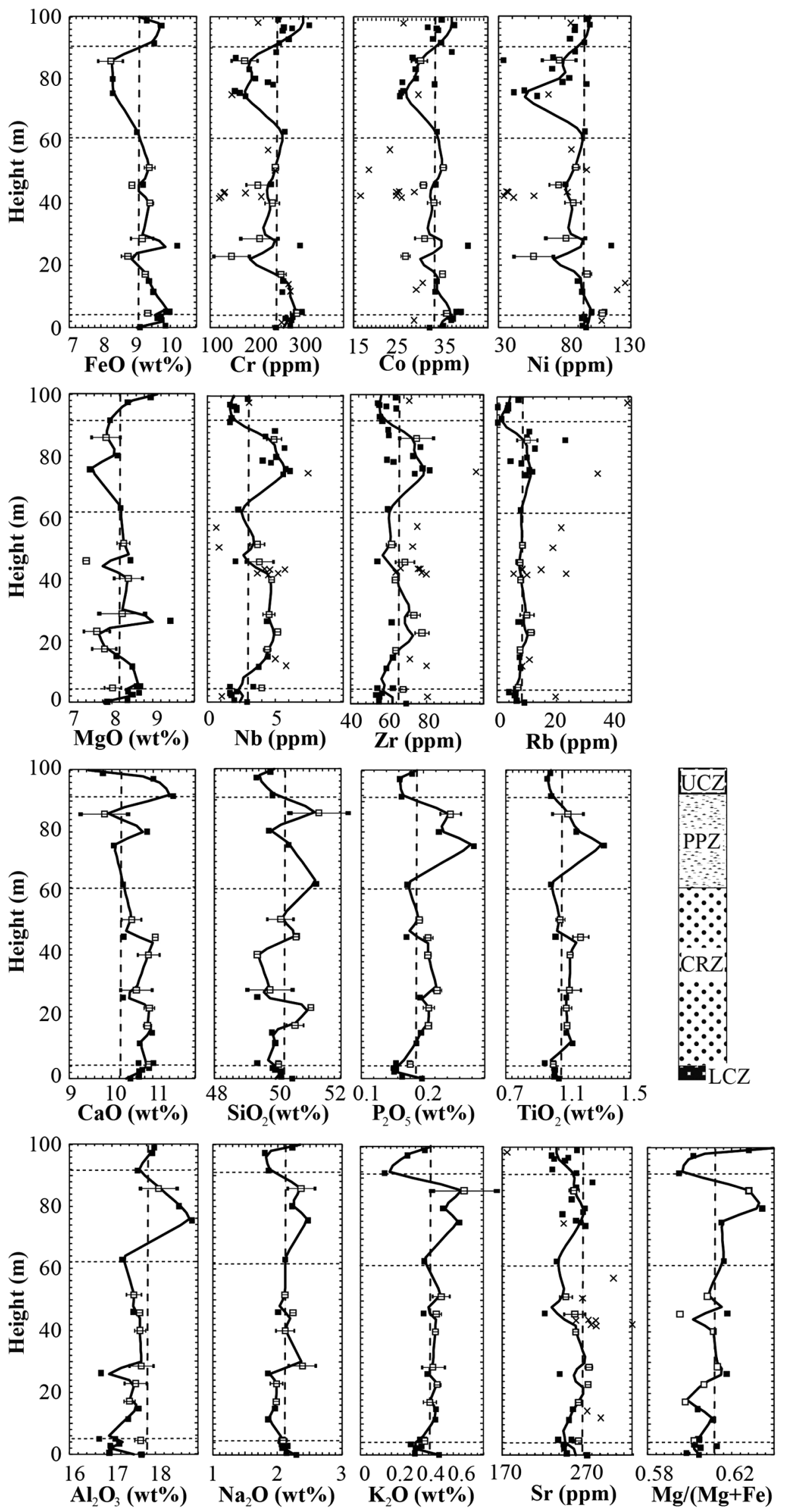

Figure 8. Vertical variations of the whole-rock concentrations of trace elements and oxides. Multiple analyses from one outcrop are averaged and plotted as open squares. Solid squares represent one analysis for each outcrop. Running averages of the averaged data taken at $2-\mathrm{m}$ intervals are shown with solid curves. Vertical dashed lines represent estimated compositions of the intruded magma. The boundaries of lithological zones are shown by dashed lines together with a lithological column on the right-hand side of the $\mathrm{TiO}_{2}$ panel. The horizontal bars represent analytical errors. Traceelement data from the southern route are shown with crosses. See Figure 5 for abbreviations of the names of the lithological zones. 
In the upper chilled zone toward the upper contact, these elements increase slightly. On the other hand, the contents of compatible elements, such as $\mathrm{Ni}, \mathrm{Cr}, \mathrm{Co}, \mathrm{FeO}$, and $\mathrm{MgO}$, increase in the lower chilled zone up to a height of $3 \mathrm{~m}$ from the lower contact; then, moving upwards, they decrease until at $30 \mathrm{~m}$, in the clinopyroxene-rich zone, following an increase (Fig. 8). From a height of $\sim 60 \mathrm{~m}$, the contents of compatible elements decrease upwards, and from $75 \mathrm{~m}$, they increase until the upper contact is reached, to give rise to a notable minimum in the plagioclase-phyric zone.

The vertical compositional variations can be summarized as follows. There are two zones with an enrichment of incompatible elements and a depletion of compatible elements at heights of 20-40 and 75-85 m from the bottom. The degree of enrichment and depletion is greater in the latter. There are two zones with a depletion of incom- patible elements and an enrichment of compatible elements at heights of 5-15 and 90-95 $\mathrm{m}$ from the bottom. At a height of $\sim 60 \mathrm{~m}$, the whole-rock composition is very similar to the chilled margin rocks.

\section{Mineralogy}

The representative chemical compositions of clinopyroxene, plagioclase, and magnetite/chromite are listed in Table 2. Because of the complete alteration of olivine in our samples, we could not determine its chemical composition.

Clinopyroxene. In most rocks, except for those from the chilled zones, the Wo content $[\mathrm{Ca} /(\mathrm{Ca}+\mathrm{Mg}+\mathrm{Fe})]$ of clinopyroxene decreases with decreasing $\mathrm{Mg} \#[\mathrm{Mg} /(\mathrm{Mg}+$ $\mathrm{Fe})$ ]. Pigeonite crystallized following the crystallization of augite in the lower chilled zone at $2.3 \mathrm{~m}$ and $4.6 \mathrm{~m}$

Table 2a. Representative chemical compositions of clinopyroxene

\begin{tabular}{|c|c|c|c|c|c|c|c|c|}
\hline Sample number & $3 b$ & $3 b$ & $4 a$ & $4 a$ & 5 & 5 & 6 & 6 \\
\hline Lithologic zone & $\mathrm{LCZ}$ & $\mathrm{LCZ}$ & $\mathrm{LCZ}$ & $\mathrm{LCZ}$ & $\mathrm{LCZ}$ & $\mathrm{LCZ}$ & $\mathrm{CRZ}$ & CRZ \\
\hline Texture & Euhedral & Euhedral & Euhedral & Euhedral & Euhedral & Euhedral & Euhedral & Euhedral \\
\hline Analytical point & $3 \mathrm{bp} \times 1$ core 1 & $3 \mathrm{bpx} 1 \mathrm{rim} 1$ & 4apx10 core 11 & 4apx10rim 11 & $5 p \times 5$ core 2 & $5 \mathrm{p} \times 5 \mathrm{rim} 3$ & $6 \mathrm{p} \times 16$ core 3 & $6 \mathrm{px} 16 \operatorname{rim} 3$ \\
\hline $\mathrm{SiO}_{2}$ & 51.74 & 51.41 & 52.60 & 51.56 & 52.44 & 51.98 & 51.86 & 50.58 \\
\hline $\mathrm{Al}_{2} \mathrm{O}_{3}$ & 3.41 & 3.03 & 2.01 & 1.62 & 2.25 & 1.84 & 2.76 & 1.89 \\
\hline $\mathrm{TiO}_{2}$ & 0.90 & 0.70 & 0.40 & 0.84 & 0.63 & 0.90 & 0.66 & 0.94 \\
\hline $\mathrm{FeO}$ & 8.88 & 9.99 & 6.90 & 12.15 & 8.07 & 13.74 & 8.16 & 14.12 \\
\hline $\mathrm{MnO}$ & 0.28 & 0.29 & 0.20 & 0.34 & 0.25 & 0.46 & 0.25 & 0.45 \\
\hline $\mathrm{MgO}$ & 15.08 & 16.24 & 17.03 & 14.67 & 15.90 & 15.90 & 16.03 & 12.93 \\
\hline $\mathrm{CaO}$ & 19.29 & 17.99 & 20.11 & 18.48 & 20.11 & 14.89 & 19.83 & 18.78 \\
\hline $\mathrm{K}_{2} \mathrm{O}$ & 0.00 & 0.00 & 0.00 & 0.00 & 0.00 & 0.01 & 0.01 & 0.04 \\
\hline $\mathrm{Na}_{2} \mathrm{O}$ & 0.26 & 0.24 & 0.24 & 0.30 & 0.26 & 0.23 & 0.20 & 0.26 \\
\hline $\mathrm{Cr}_{2} \mathrm{O}_{3}$ & 0.17 & 0.11 & 0.46 & 0.00 & 0.08 & 0.00 & 0.20 & 0.00 \\
\hline $\mathrm{NiO}$ & 0.00 & 0.00 & 0.05 & 0.04 & 0.00 & 0.04 & 0.04 & 0.00 \\
\hline Total & 99.57 & 100.67 & 100.80 & 100.48 & 99.32 & 100.00 & 100.03 & 99.84 \\
\hline Sample number & 8 & 8 & 12 & 12 & 18 & 18 & 23 & 23 \\
\hline Lithologic zone & CRZ & CRZ & CRZ & CRZ & PPZ & PPZ & UCZ & $\mathrm{UCZ}$ \\
\hline Texture & Euhedral & Euhedral & Ophitic & Ophitic & Euhedral & Euhedral & - & - \\
\hline Analytical point & $8 \mathrm{px} 6$ core 1 & $8 \mathrm{px} 6$ rim 1 & $12 \mathrm{px} 17$ core 2 & 12px17rim 2 & $18 \mathrm{px} 1$ core 2 & $18 \mathrm{px} 1 \mathrm{rim} 1$ & $23 \mathrm{p} \times 13$ core 2 & 23px13rim 1 \\
\hline $\mathrm{SiO}_{2}$ & 52.82 & 50.94 & 51.21 & 51.08 & 53.27 & 51.81 & 51.27 & 51.70 \\
\hline $\mathrm{Al}_{2} \mathrm{O}_{3}$ & 1.65 & 2.57 & 2.46 & 2.23 & 1.66 & 1.49 & 3.51 & 3.07 \\
\hline $\mathrm{TiO}_{2}$ & 0.47 & 1.00 & 0.69 & 1.05 & 0.44 & 0.79 & 0.75 & 0.74 \\
\hline $\mathrm{FeO}$ & 7.83 & 13.89 & 7.91 & 11.54 & 7.09 & 12.54 & 8.16 & 9.68 \\
\hline $\mathrm{MnO}$ & 0.26 & 0.41 & 0.22 & 0.34 & 0.29 & 0.36 & 0.23 & 0.26 \\
\hline $\mathrm{MgO}$ & 17.33 & 14.36 & 16.05 & 14.27 & 17.90 & 15.33 & 16.13 & 14.56 \\
\hline $\mathrm{CaO}$ & 19.14 & 16.55 & 21.01 & 19.23 & 18.87 & 17.42 & 19.02 & 19.69 \\
\hline $\mathrm{K}_{2} \mathrm{O}$ & 0.00 & 0.02 & 0.00 & 0.00 & 0.00 & 0.01 & 0.00 & 0.02 \\
\hline $\mathrm{Na}_{2} \mathrm{O}$ & 0.16 & 0.25 & 0.25 & 0.27 & 0.16 & 0.22 & 0.23 & 0.24 \\
\hline $\mathrm{Cr}_{2} \mathrm{O}_{3}$ & 0.28 & 0.00 & 0.18 & 0.00 & 0.32 & 0.02 & 0.70 & 0.03 \\
\hline $\mathrm{NiO}$ & 0.05 & 0.00 & 0.03 & 0.00 & 0.00 & 0.01 & 0.00 & 0.00 \\
\hline Total & 100.25 & 99.29 & 100.05 & 100.28 & 99.53 & 100.08 & 100.67 & 99.82 \\
\hline
\end{tabular}

Abbreviations: px, pyroxene; -, no data; UCZ, upper chilled zone; PPZ, plagioclase-phyric zone; CRZ, clinopyroxene-rich zone; LCZ, lower chilled zone. 
Table 2b. Representative chemical compositions of phenocryst and matrix plagioclase

\begin{tabular}{|c|c|c|c|c|c|c|c|c|}
\hline Sample number & $3 b$ & $3 b$ & $4 a$ & $4 a$ & 5 & 5 & 6 & 6 \\
\hline Lithologic zone & $\mathrm{LCZ}$ & $\mathrm{LCZ}$ & $\mathrm{LCZ}$ & $\mathrm{LCZ}$ & $\mathrm{LCZ}$ & $\mathrm{LCZ}$ & CRZ & CRZ \\
\hline Texture & Matrix & Matrix & Phenocryst & Phenocryst & Phenocryst & Phenocryst & Matrix & Matrix \\
\hline Analytical point & $3 b p l 14$ core 1 & $3 \mathrm{bpl14}$ rim1 & 4apl50 core 2 & 4apl50 rim1 & $5 \mathrm{pl} 34$ core 3 & 5 pl34 riml & $6 \mathrm{p} 12$ core 1 & $6 \mathrm{pl} 2 \mathrm{rim} 1$ \\
\hline $\mathrm{SiO}_{2}$ & 47.92 & 47.64 & 46.02 & 53.05 & 45.99 & 55.00 & 48.35 & 55.41 \\
\hline $\mathrm{Al}_{2} \mathrm{O}_{3}$ & 32.87 & 32.89 & 34.27 & 29.21 & 34.23 & 27.83 & 32.99 & 27.93 \\
\hline $\mathrm{TiO}_{2}$ & 0.07 & 0.04 & 0.03 & 0.08 & 0.07 & 0.11 & 0.02 & 0.10 \\
\hline $\mathrm{FeO}$ & 0.74 & 0.69 & 0.55 & 0.82 & 0.64 & 0.68 & 0.58 & 0.85 \\
\hline $\mathrm{MnO}$ & 0.01 & 0.02 & 0.03 & 0.02 & 0.00 & 0.00 & 0.02 & 0.01 \\
\hline $\mathrm{MgO}$ & 0.12 & 0.11 & 0.15 & 0.10 & 0.07 & 0.06 & 0.13 & 0.09 \\
\hline $\mathrm{CaO}$ & 16.30 & 16.92 & 17.90 & 12.64 & 17.86 & 11.15 & 16.11 & 11.05 \\
\hline $\mathrm{K}_{2} \mathrm{O}$ & 0.05 & 0.05 & 0.04 & 0.12 & 0.01 & 0.18 & 0.04 & 0.18 \\
\hline $\mathrm{Na}_{2} \mathrm{O}$ & 1.91 & 1.63 & 1.02 & 3.96 & 1.09 & 4.97 & 1.76 & 4.40 \\
\hline $\mathrm{Cr}_{2} \mathrm{O}_{3}$ & 0.00 & 0.02 & 0.00 & 0.00 & 0.00 & 0.00 & 0.00 & 0.00 \\
\hline $\mathrm{NiO}$ & 0.02 & 0.00 & 0.00 & 0.00 & 0.07 & 0.02 & 0.00 & 0.00 \\
\hline Total & 100.70 & 99.31 & 100.66 & 100.76 & 100.21 & 100.68 & 99.65 & 100.13 \\
\hline Sample number & 8 & 8 & 10 & 10 & 12 & 12 & 23 & 23 \\
\hline Lithologic zone & CRZ & CRZ & CRZ & CRZ & CRZ & CRZ & UCZ & UCZ \\
\hline Texture & Matrix & Matrix & Matrix & Matrix & Matrix & Matrix & Phenocryst & Phenocryst \\
\hline Analytical point & $8 \mathrm{pl} 3$ core 2 & $8 \mathrm{pl} 3$ rim 1 & $10 \mathrm{pl1}$ core 1 & 10pl1 rim1 & $12 \mathrm{pl} 14$ core 2 & 12pl14 rim1 & $23 \mathrm{pl} 2$ core 6 & $23 \mathrm{p} 12 \operatorname{rim} 7$ \\
\hline $\mathrm{SiO}_{2}$ & 49.56 & 56.88 & 49.50 & 51.57 & 53.45 & 56.65 & 46.28 & 51.01 \\
\hline $\mathrm{Al}_{2} \mathrm{O}_{3}$ & 31.66 & 26.96 & 31.66 & 30.28 & 28.86 & 26.96 & 33.95 & 29.87 \\
\hline $\mathrm{TiO}_{2}$ & 0.03 & 0.07 & 0.06 & 0.05 & 0.11 & 0.09 & 0.03 & 0.03 \\
\hline $\mathrm{FeO}$ & 0.63 & 0.66 & 0.68 & 0.69 & 0.76 & 0.52 & 0.54 & 0.63 \\
\hline $\mathrm{MnO}$ & 0.05 & 0.00 & 0.01 & 0.00 & 0.03 & 0.04 & 0.01 & 0.00 \\
\hline $\mathrm{MgO}$ & 0.16 & 0.08 & 0.20 & 0.15 & 0.12 & 0.06 & 0.15 & 0.22 \\
\hline $\mathrm{CaO}$ & 15.43 & 9.63 & 15.59 & 13.98 & 12.38 & 9.90 & 17.94 & 15.12 \\
\hline $\mathrm{K}_{2} \mathrm{O}$ & 0.05 & 0.20 & 0.07 & 0.09 & 0.13 & 0.24 & 0.00 & 0.06 \\
\hline $\mathrm{Na}_{2} \mathrm{O}$ & 2.40 & 5.49 & 2.18 & 3.13 & 4.17 & 5.50 & 1.07 & 3.06 \\
\hline $\mathrm{Cr}_{2} \mathrm{O}_{3}$ & 0.01 & 0.02 & 0.02 & 0.03 & 0.00 & 0.00 & 0.03 & 0.01 \\
\hline $\mathrm{NiO}$ & 0.01 & 0.00 & 0.03 & 0.03 & 0.01 & 0.04 & 0.01 & 0.00 \\
\hline Total & 99.35 & 99.47 & 100.03 & 100.67 & 100.32 & 99.83 & 99.37 & 99.75 \\
\hline
\end{tabular}

Abbreviations: pl, plagioclase; UCZ, upper chilled zone; PPZ, plagioclase-phyric zone; CRZ, clinopyroxene-rich zone; LCZ, lower chilled zone.

Table 2c. Representative chemical compositions of magnetite and chromian spinel.

\begin{tabular}{|c|c|c|c|c|c|c|}
\hline Sample number & 1201 & 1206 & 1206 & 2814 & 23 & 23 \\
\hline Lithologic zone & CRZ & CRZ & CRZ & PPZ & UCZ & UCZ \\
\hline Analytical point & $1201 \mathrm{mgt} 7 \mathrm{rim} 1$ & $1206 \mathrm{mgt} 5$ core 2 & $1206 \mathrm{mgt} 1 \mathrm{rim} 1$ & 2814mgtrim2 & 23 sp2core 2 & 23 sp 1 rim 1 \\
\hline $\mathrm{SiO}_{2}$ & 0.11 & 0.08 & 0.11 & 0.70 & 0.05 & 0.09 \\
\hline $\mathrm{MgO}$ & 0.00 & 0.01 & 0.01 & 0.22 & 8.58 & 6.63 \\
\hline $\mathrm{Al}_{2} \mathrm{O}_{3}$ & 1.40 & 2.31 & 1.68 & 1.68 & 15.65 & 12.15 \\
\hline $\mathrm{TiO}_{2}$ & 21.11 & 20.52 & 19.70 & 21.65 & 0.85 & 2.68 \\
\hline $\mathrm{MnO}$ & 3.64 & 4.28 & 3.78 & 5.16 & 0.34 & 0.36 \\
\hline $\mathrm{NiO}$ & 0.02 & 0.03 & 0.00 & 0.03 & 0.08 & 0.07 \\
\hline $\mathrm{Cr}_{2} \mathrm{O}_{3}$ & 0.04 & 0.06 & 0.04 & 0.02 & 40.53 & 34.28 \\
\hline $\mathrm{FeO}$ & 46.27 & 44.60 & 44.30 & 45.90 & 21.66 & 25.80 \\
\hline $\mathrm{Fe}_{2} \mathrm{O}_{3}$ & 23.84 & 22.76 & 25.03 & 21.65 & 12.36 & 18.37 \\
\hline Total & 96.48 & 94.66 & 94.65 & 97.02 & 100.10 & 100.42 \\
\hline
\end{tabular}

Abbreviations: mgt, magnetite; sp, spinel; UCZ, upper chilled zone; PPZ, plagioclase-phyric zone; CRZ, clinopyroxene-rich zone; LCZ, lower chilled zone. 


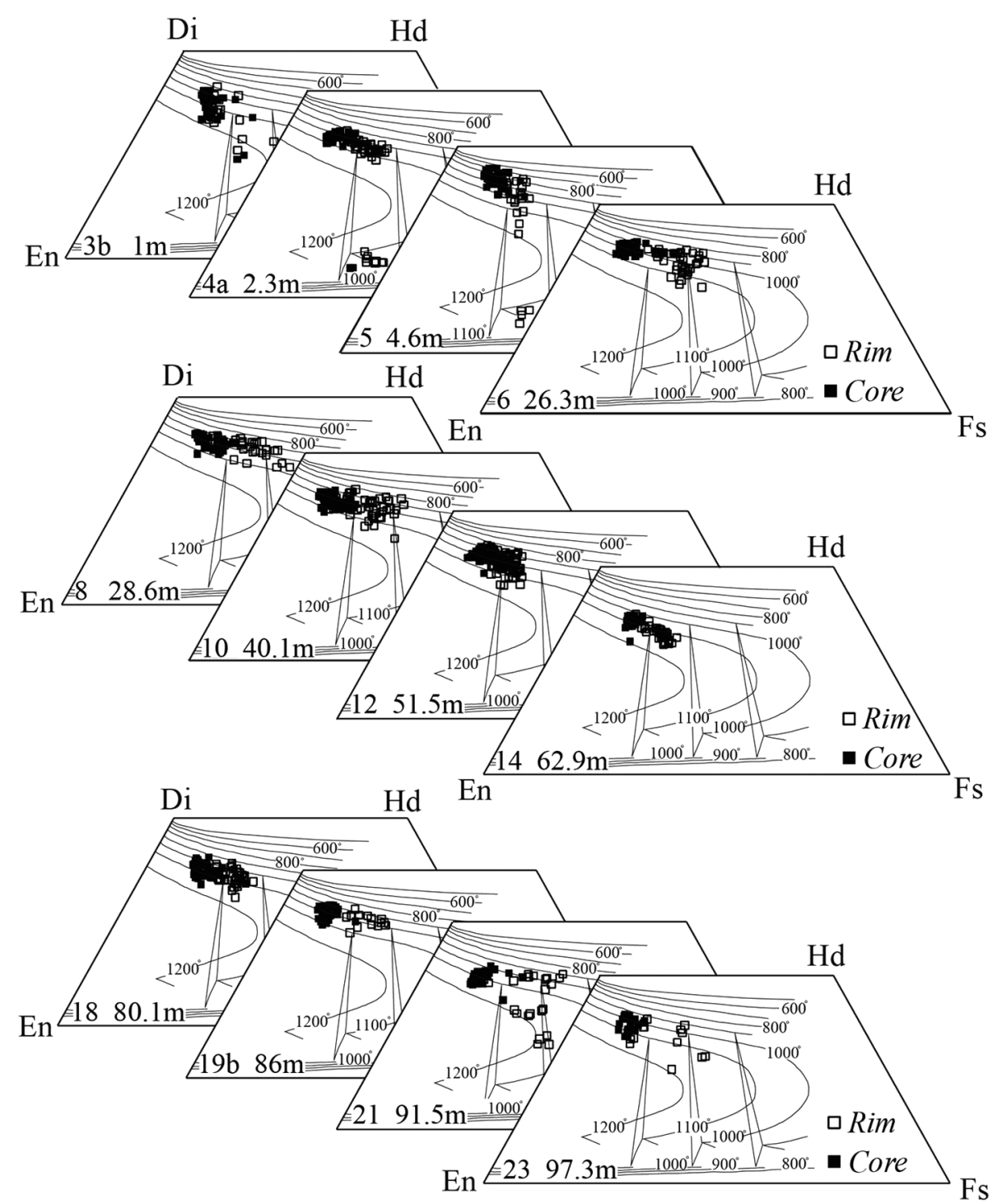

Figure 9. Pyroxene compositions from Aosawa dolerite II plotted in pyroxene quadrilateral. Sample number and height above the bottom of this intrusion are given on the lower left side of each quadrilateral. Minor elements such as $\mathrm{Al}, \mathrm{Cr}$, and $\mathrm{Na}$ are subtracted to project onto the quadrilateral using the method of Lindsley (1983). The contours are isotherms of the pyroxene thermometer at $1 \mathrm{~atm}$ (Lindsley, 1983). above the bottom (Figs. 3 and 9). Thus, we can estimate the crystallization temperature of pigeonite by assuming equilibrium between augite and pigeonite in contact with each other (Fig. 3). It is $1100^{\circ} \mathrm{C}$, on the basis of the pyroxene phase relation in the $\mathrm{Ca}-\mathrm{Mg}-\mathrm{Fe}$ quadrilateral (Lindsley, 1983) (sample 4a in Fig. 9).

Clinopyroxene crystals exhibit a normal zoning, irrespective of their morphology (euhedral or ophitic); the $\mathrm{Mg} \#$ is higher at the core (0.8-0.9) than at the rim (0.50.8 ), and the $\mathrm{Cr}_{2} \mathrm{O}_{3}$ content is generally greater at the core than at the rim. Clinopyroxene in rocks from the chilled zone has a consistent core composition, and the subcalcic rim compositions show a large scatter (samples $3 b, 21$, and 23 in Fig. 9). Oscillatory and/or sector zoning are often observed in large clinopyroxene crystals. $\mathrm{The} \mathrm{Cr}_{2} \mathrm{O}_{3}$ content at the core is fairly scattered, ranging from $0-1.0$ $\mathrm{wt} \%$, even in a single rock sample (Fig. 10). Within each clinopyroxene grain, the range of chemical variation is as broad as the variation over the entire intrusion (Fig. 10).

The spectrum of chemical heterogeneity of clinopryoxene is moderate at the both contacts. It increases inwards up to $30 \mathrm{~m}$ from the bottom and $10 \mathrm{~m}$ from the top, and then decreases toward the center, with a minimum at a height of $\sim 60 \mathrm{~m}$ (Fig. 10). This is mainly attributed to a reduced variation in the rim compositions, with minor contributions from the core variation. For example, at $60 \mathrm{~m}$, the $\mathrm{Mg} \#$ of clinopyroxene is consistent within 0.2 , primarily due to the gradual increase of the rim values (both the minimum and the average) from above and below. The core Mg\# shows a subtle yet systematic variation, which is antithetic to the rim variation in terms of both the maximum and average (Fig. 10). The $\mathrm{Cr}$ content shows the same variation pattern as that of $\mathrm{Mg} \#$, although the variation in the minimum values is not clearly manifested (Fig. 10). The Ti and Mn contents show the same tendencies, albeit more pronounced, and are opposite to 


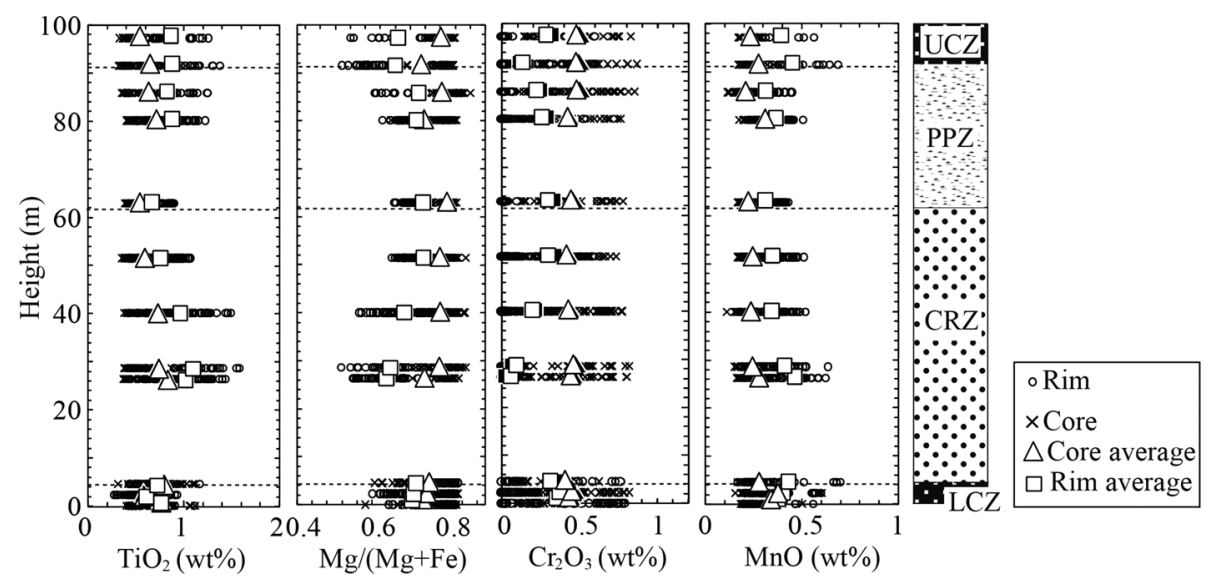

Figure 10. Vertical variation of $\mathrm{TiO}_{2}$, $\mathrm{Mg} /(\mathrm{Mg}+\mathrm{Fe}), \mathrm{Cr}_{2} \mathrm{O}_{3}$, and $\mathrm{MnO}$ contents in clinopyroxene. Crosses represent the core; open circles, the rim; large open triangles, the average of the core data; and large open squares, the average of the rim data. The horizontal dotted lines correspond to the boundaries of the lithological zones, shown on the right. See Figure 5 for abbreviations of the names of the lithological zones.

the variation of $\mathrm{Mg \#} \mathrm{(Fig.} \mathrm{10).}$

Plagioclase, olivine, and magnetite/chromite. Plagioclase phenocrysts, which frequently form aggregates and are abundant in the plagioclase-phyric zone, have an An content $[(100 \times \mathrm{Ca}) /(\mathrm{Ca}+\mathrm{Na}+\mathrm{K})]$ higher than that of finer matrix plagioclase. Such plagioclase phenocrysts have a core with an An content ranging from 80 to 90, showing weak oscillatory zoning, and an An-poor rim (An $=70-80$ ). On the other hand, the composition of the matrix plagioclase has $A n=65-85$ at the core, which are within the range of the An of the phenocryst rim, and An $=40-65$ at the rim. The vertical variation in An content is characterized by moderate heterogeneity at $\sim 60 \mathrm{~m}$ and notable heterogeneity in the middle of the clinopyroxenerich zone, $30 \mathrm{~m}$ from the bottom. This trend is the same as that of the vertical variation in heterogeneity of clinopyroxene compositions such as $\mathrm{Mg \#}$ and $\mathrm{Ti}$ (Fig. 10).

We examined olivine crystals in the rocks and found that they are all altered to clay minerals. Fujii (1974a) reported $\mathrm{Fo}=68-79[\mathrm{Fo}=(100 \times \mathrm{Mg}) /(\mathrm{Mg}+\mathrm{Fe})]$ olivine from Aosawa dolerite I, which is comparable to the $\mathrm{Mg \#}$ of the clinopyroxene core described above. In a sample from the UCZ at a height of $95 \mathrm{~m}$, chromite is present in olivine phenocrysts as inclusions, which contain 1-3 wt $\%$ $\mathrm{TiO}_{2}$ (Table 2). Magnetite contains less than $1 \mathrm{wt} \% \mathrm{Cr}_{2} \mathrm{O}_{3}$ (Table 2).

Cr-rich clinopyroxene: internal structure and distribution in the intrusion. Clinopyroxene in the sill shows a wide variation in $\mathrm{Cr}_{2} \mathrm{O}_{3}$ content, as presented in Figures. 10 and 11. The $\mathrm{Cr}_{2} \mathrm{O}_{3}$ content in the core is characterized by a bimodal distribution, irrespective of whether a single sample in a particular zone, or the whole intrusion, is being considered. One peak appears at $0.1-0.3 \mathrm{wt} \%$, and the other at $0.6-0.8$ wt $\%$ in $\mathrm{Cr}_{2} \mathrm{O}_{3}$ content (Fig. 11). Both the $\mathrm{Cr}$-rich and $\mathrm{Cr}$-poor cores coexist in one sample (Figs. $12 \mathrm{a}$ and $12 \mathrm{~b}$ ). This is partly due to the sectioning of a
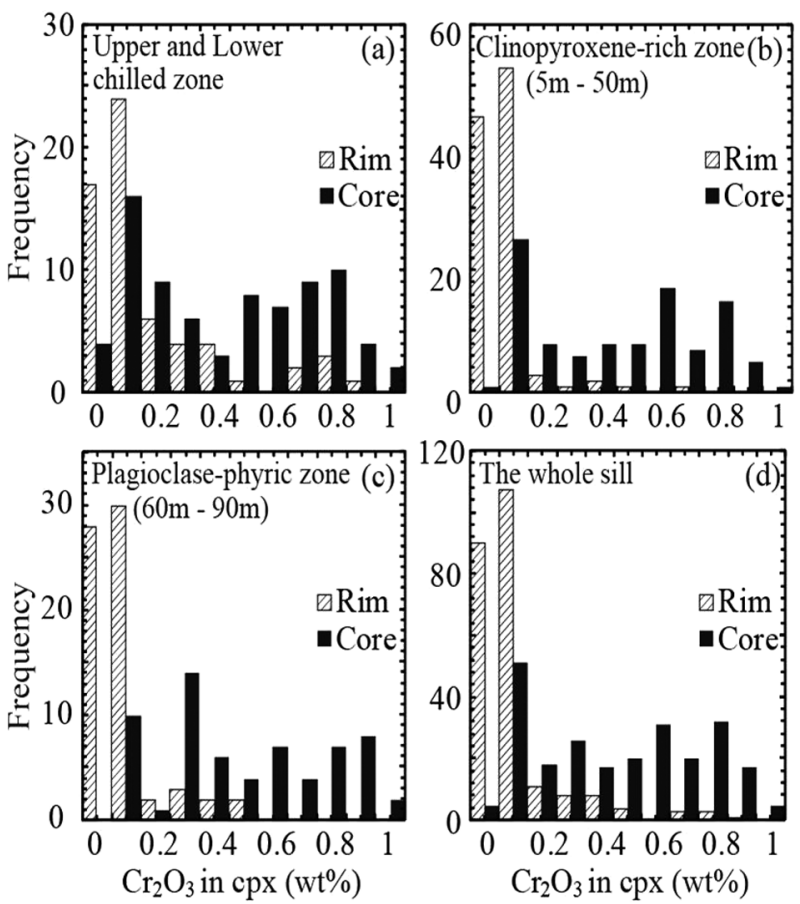

Figure 11. Histogram of $\mathrm{Cr}_{2} \mathrm{O}_{3}$ contents in the core and rim of clinopyroxene (cpx). The vertical axis represents the frequency of measurements. (a) Histogram of $\mathrm{Cr}_{2} \mathrm{O}_{3}$ contents of clinopyroxene in samples from the UCZ and LCZ (samples no. 1303b, 1304a, and 1323). (b) Histogram from the CRZ (samples no. 1305, 1306, 1308, 1310, and 1312). (c) Histogram from the PPZ (samples no. 1314, 1318, 1319b, and 1321). (d) Histogram from clinopyroxene in all measured samples.

zoned three-dimensional crystal, but there is no systematic relationship between the size and the two types of clinopyroxene. Moreover, the abundance of $\mathrm{Cr}$-rich clinopyroxene shows a systematic spatial variation, as shown below, which cannot be explained simply by the cutting effect of sector-zoned crystals. The $\mathrm{Cr}_{2} \mathrm{O}_{3}$ content in the rim is consistently lower than that in the core, and the distribution is generally unimodal (Fig. 11), with the rare oc- 


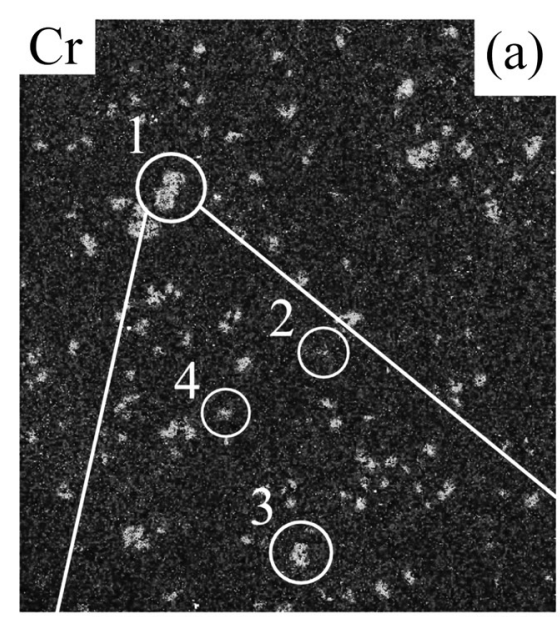
RGB overlay map
(Red:Fe, Green: $\mathrm{Ca}, \mathrm{Blue} A \mathrm{Al})$
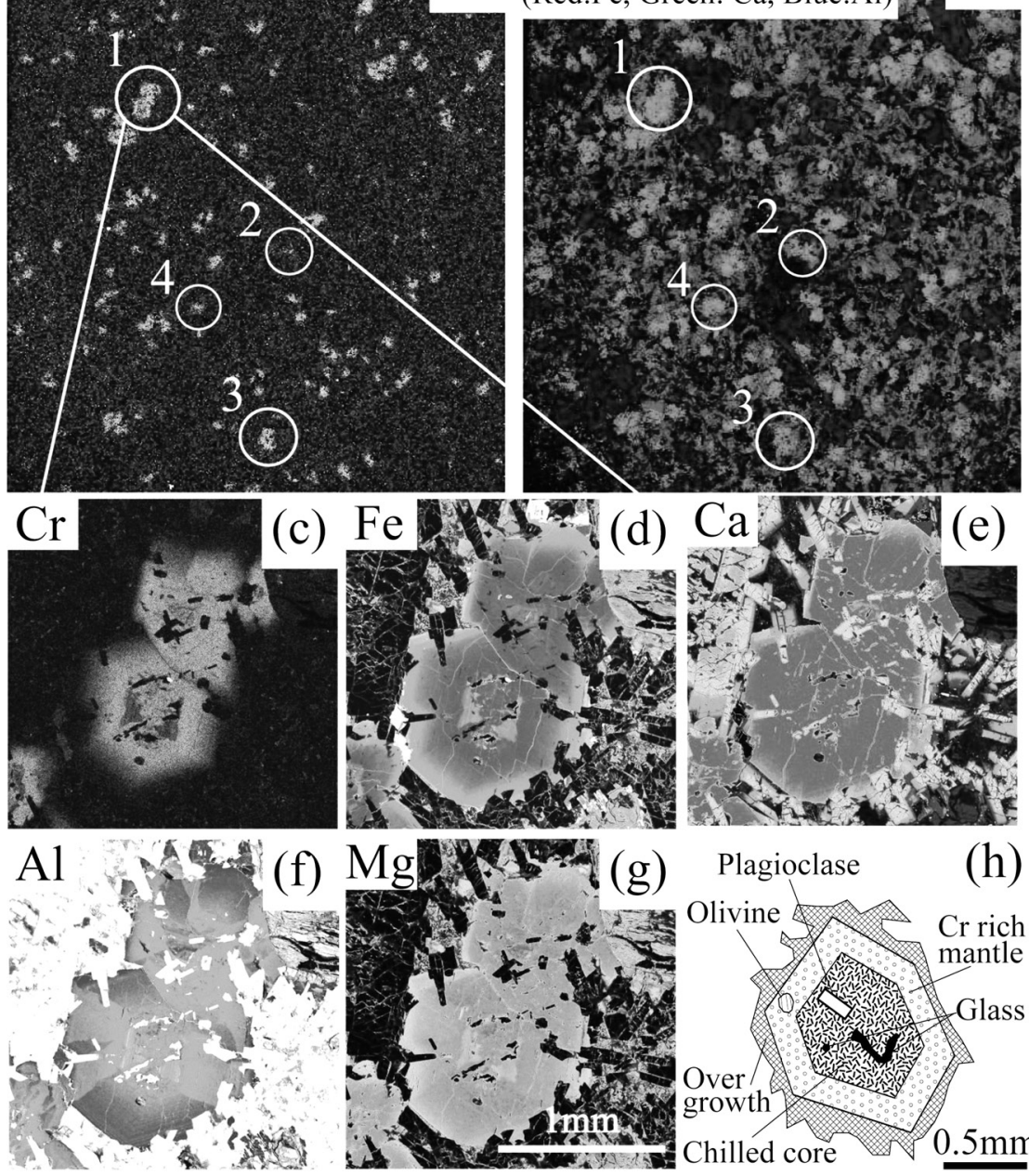

Plagioclase

(h)

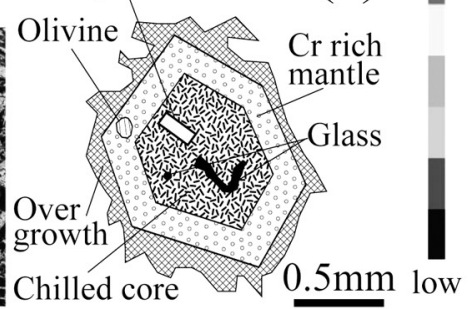

Figure 12. X-ray intensity maps of a sample $5 \mathrm{~m}$ from the bottom, belonging to the CRZ. (a) Cr distribution, in which yellow (or bright) areas represent $\mathrm{Cr}$-rich clinopyroxene $\left(\mathrm{Cr}_{2} \mathrm{O}_{3}>0.46\right.$ wt\%). (b) RGB overlay map with $\mathrm{Fe}$ in red, $\mathrm{Ca}$ in green, and $\mathrm{Al}$ in blue. Green (or bright) areas represent clinopyroxene; red, magnetite; light blue, plagioclase; dark blue, glass; and dark red, olivine. The white circles labeled 1 and 3 are $\mathrm{Cr}$-rich clinopyroxene, and those labeled 2 and 4 are $\mathrm{Cr}$-poor clinopyroxene. (c)-(g) Detailed elemental distribution $(\mathrm{Cr}, \mathrm{Fe}, \mathrm{Ca}, \mathrm{Al}$, and $\mathrm{Mg}$ ) in the $\mathrm{Cr}$-rich clinopyroxene labeled 1. (h) Schematic illustration of zoning and texture of $\mathrm{Cr}^{-}$ rich clinopyroxene. Note that $\mathrm{Cr}$ rich magnetite occurs on the inner side of the Cr-rich mantle, as shown by the Cr map (c). (Color version of Figure 12 is available online from http://joi.jlc.jst.go.jp/JST.JSTAGE/ jmps/100306.) currence of a Cr-rich rim (Fig. 11a).

The Cr-rich clinopyroxene exhibits a peculiar zoning, as illustrated in Figure 12c-12g. It has a core with remarkable sector zoning ( $\mathrm{Fe}, \mathrm{Al}, \mathrm{Cr}$, and $\mathrm{Mg}$ ) and oscillatory zoning $(\mathrm{Al}, \mathrm{Cr})$. The core is, on average, richer in $\mathrm{Mg}, \mathrm{Cr}$, and $\mathrm{Al}$ than the rim. The core is also characterized by the inclusions of small plagioclase laths $\sim 150 \mu \mathrm{m}$ in size, as well as glass inclusions (Fig. 12h). In this paper, such a core is called a chilled core because of the textures, which indicate rapid growth due to high supersaturation. The chilled core is invariably surrounded by a $\mathrm{Cr}-$ and $\mathrm{Mg}$-rich zone, where small olivine grains and $\mathrm{Cr}$-rich magnetite, $\sim 50$ and $\sim 40 \mu \mathrm{m}$ in size, respectively, are included along the outer zone. Plagioclase inclusions are not present in this zone. This layer is called the $\mathrm{Cr}$-rich mantle, which is characterized by the absence of sector zoning (Fig. 12h). The Cr-rich mantle is surrounded by an $\mathrm{Fe}$-rich and $\mathrm{Cr}$-poor margin, with a notable enrichment of Fe and a depletion of Cr toward the outermost rim. This margin shows intergrowth with plagioclase, giving rise to an ophitic or subophitic texture in the clinopyroxene-rich zone. This margin is referred to as overgrowth in this work. The thickness of the overgrowth is less in the upper part (70-80 $\mathrm{m}$ from the bottom) than it is in the lower part (5-25 $\mathrm{m})$ of the intrusion.

In order to evaluate the abundance of $\mathrm{Cr}_{2} \mathrm{O}_{3}$-rich and $\mathrm{Cr}_{2} \mathrm{O}_{3}$-poor clinopyroxene, extensive mapping analyses were carried out for 18 samples (e.g., Figs. 12a and 12b). As expected from the histograms shown in Fig. 11, the distinction of two types of clinopyroxene crystals is rather easy. For quantification of the two types of clinopyroxene, we used $\mathrm{Cr}_{2} \mathrm{O}_{3}=0.46 \mathrm{wt} \%$ as a boundary value, according to Figure 11. The result of the vertical modal distribution of $\mathrm{Cr}$-rich clinopyroxenes is shown in Figure 13. The abundance of $\mathrm{Cr}$-rich clinopyroxene is almost constant at 2-3 vol\%, with a subtle increase when moving toward a height of $20 \mathrm{~m}$ from the bottom. There is a zone with a high concentration of $\mathrm{Cr}$-rich clinopyroxene (approximately $5 \mathrm{vol} \%$ ) at $5-15 \mathrm{~m}$ from the bottom. The abundance rapidly, but continuously, decreases toward the 


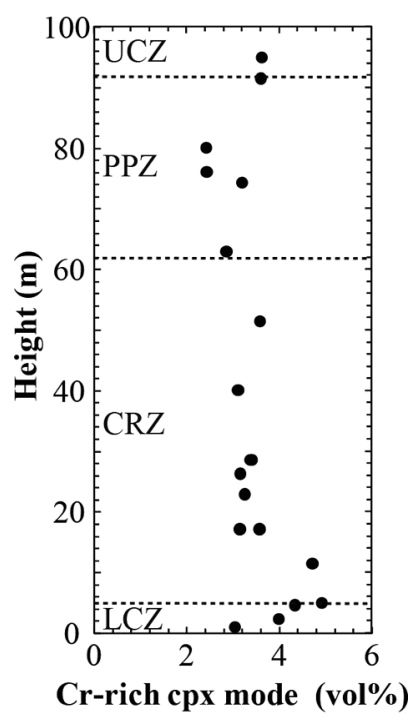

Figure 13. Vertical variation of the mode of $\mathrm{Cr}$-rich clinopyroxene (cpx) estimated from $\mathrm{Cr} \mathrm{X}$-ray mapping. The four lithological zones, which are defined in Figure 5, are shown with horizontal broken lines.

lower chilled margin.

\section{FORMATION PROCESS OF AOSAWA DOLERITE II}

\section{Lateral variation, the origin of the sedimentary rock interval, and the intrusion process}

The vertical variations in trace elements in the dolerite sill along the northern valley, as described above, were compared with those from the southern valley (see Fig. 1 for its location). The two data sets are comparable, except for a large scatter in the southern section at $40-60 \mathrm{~m}$ from the bottom (Fig. 8). The scatter is due to the higher and variable abundunce of $\mathrm{Sr}$ and lower abundunce of $\mathrm{Co}, \mathrm{Cr}$, and $\mathrm{Ni}$, suggesting a local and variable enrichment or depletion of plagioclase. The increased abundance of large plagioclase crystals at this height was observed in the southern valley. The trace element variations, particularly those of $\mathrm{Nb}$ and $\mathrm{Cr}$, and the similar petrographic variations along the two routes, suggest that the sill has a minor lateral variation over a distance of at least $2 \mathrm{~km}$.

There is a sedimentary rock interval at $65-70 \mathrm{~m}$ in height along the northern valley (Fig. 1). It is critical to check whether the interval represents a sedimentary block entrapped in the intruded magma, or if it represents a 5-m-thick sedimentary-rock layer dividing the studied sill into two isolated intrusions. There are three lines of evidence that support the former interpretation. (1) There is no clinopyroxene in the upper chilled margin, but clinopyroxene phenocrysts are observed in fine-grained por- phyritic dolerite that is in contact with the internal sedimentary rock. (2) The whole-rock content of $\mathrm{Nb}$, which is not easily affected by alteration (Anderson and Hawkes, 1958), is clearly different from that of the upper chilled margin (Fig. 8). (3) The compositional and textual variations throughout the sill, including above and below the sedimentary interval, show smooth variations. Another supporting observation is the absence of such internal sedimentary rock in the southern valley (Fig. 1). There are no chilled zones within the sill, as shown by the size variation of the interstitial plagioclase (Figs. 2e and 2f). Moreover, the density of the sedimentary rock (2600$2700 \mathrm{~kg} / \mathrm{m}^{3}$ ) is close to that of the initial melt, as estimated below, suggesting a very slow settling of the sedimentary rock (Holm, 1954).

The smooth variations in the mode and number density of clinopyroxene and no internal chilled horizons, as demonstrated by the smooth variation in the size and morphology of matrix plagioclase, suggest that Aosawa dolerite II was formed in one or multiple intrusion pulses within a time scale much smaller than that of the cooling, during which the sill solidified to behave as a solid ( $40 \%$ crystallinity). This inference is also supported by the fact that the upper and lower chilled margin rocks are the same as the entire intrusion in terms of the chemical composition, as will be demonstrated below.

Aosawa dolerite II is inferred to have intruded after the consolidation of the host rocks, and that the sedimentary interval represents a block of mudstone incorporated during the intrusion. The occurrence of clinopyroxene crystals near the sedimentary rock suggests that a cold block of sedimentary rock was peeled from the roof, after the intruded magma underwent a certain extent of fractionation.

\section{Initial condition of the magma}

The projected core compositions of augite from the upper chilled zones are mainly clustered around the $1100{ }^{\circ} \mathrm{C}$ contour, and some data are plotted on the $1200{ }^{\circ} \mathrm{C}$ contour (sample $3 \mathrm{~b}$ in Fig. 9). The data cluster is elongated, and there is a large variation in the Wo content, which is rather different compared to the tighter trend inside the sill. This suggests the dynamic crystallization of augite in the chilled zones. The data cluster for the inside of the sill extends almost parallel to the isotherms overlapping with $1000-1100{ }^{\circ} \mathrm{C}$ contours (Fig. 9), which indicates the crystallization temperature was $>1100{ }^{\circ} \mathrm{C}$ because of the undersaturation of orthopyroxene. As mentioned above, pigeonite rimming augite in the lower part of the sill indicates a crystallization temperature of $\sim 1100{ }^{\circ} \mathrm{C}$. Considering the absence of augite phenocrysts in the chilled 
margins, these thermometries suggest that the temperature of the intruded magma was higher than $\sim 1100{ }^{\circ} \mathrm{C}$. The depth of the intrusion is estimated to be $\sim 0.15 \pm 0.03 \mathrm{GPa}$ based on the planar morphology of the sill concordant with the bedding plane, which implies that intrusion occurred after significant compaction of sediments (Simura and Ozawa, 2006). Tsuchiya (1989a, 1989b) reported irregular intrusion contacts and mudstone inclusions with a size of a few meters from other intrusions, arguing that those intrusions formed while the host sediments were still soft. The planar contact of the studied intrusion, in contrast to the observations of Tsuchiya, suggests its emplacement into the consolidated sedimentary rocks, being in support of our depth estimates.

The composition of the initial magmas, including the crystals present at the time of intrusion (phenocrysts), were estimated by averaging the whole-rock chemical composition of samples in the upper chilled zone $(5 \mathrm{~cm}$ from the upper contact) and in the lower chilled zone (within a meter from the lower contact). We did not use rocks directly at the contacts as they are strongly altered, the bulk compositions of which are not appropriate for this purpose. The average compositions with $1 \sigma$ errors are presented in Table 3. The data for the upper and lower chilled margins, which are very similar, are also presented. The estimated initial magma composition is plotted in Figure 8 as vertical broken lines to compare with the vertical variation in the sill. The estimated composition is compared with the composition of the entire sill calculated from the vertical variation (Table 3 ). They are almost identical, if analytical errors are taken into consideration. These facts suggest that the intruded magma was homogeneous and crystallization processes took place in a closed system after a single intrusion pulse or multiple pulses of a homogeneous magma over a short interval, as inferred above.

The amount of crystals already present in the intruded magma can be estimated from the phenocryst abundance in the chilled margins, estimated to be 5.3 vol\% for olivine and 1.9 vol $\%$ for plagioclase. The water content in the intruded magma is estimated from the equilibrium between the initial melt, the composition of which was esti-

Table 3. Average compositions and $1 \sigma$ errors of rocks from the chilled margins and those of the entire sill

\begin{tabular}{|c|c|c|c|c|c|c|c|}
\hline & \multicolumn{2}{|c|}{ Average of the chilled margins } & \multirow[t]{2}{*}{ Upper chilled margin } & \multicolumn{2}{|c|}{ Lower chilled margin } & \multicolumn{2}{|c|}{ Entire intrusion } \\
\hline & Average & $1 \sigma$ & & Average & $1 \sigma$ & Average* & $1 \sigma$ \\
\hline $\mathrm{wt} \%$ & & & & & & & \\
\hline $\mathrm{SiO}_{2}$ & 50.24 & 0.40 & 49.78 & 50.47 & 0.05 & 50.21 & 0.52 \\
\hline $\mathrm{TiO}_{2}$ & 1.02 & 0.04 & 0.98 & 1.04 & 0.02 & 1.08 & 0.08 \\
\hline $\mathrm{Al}_{2} \mathrm{O}_{3}$ & 17.78 & 0.20 & 17.97 & 17.68 & 0.15 & 17.66 & 0.44 \\
\hline $\mathrm{FeO}$ & 9.30 & 0.13 & 9.45 & 9.23 & 0.02 & 9.26 & 0.48 \\
\hline $\mathrm{MnO}$ & 0.21 & 0.01 & 0.22 & 0.20 & 0.00 & 0.19 & 0.02 \\
\hline $\mathrm{MgO}$ & 8.26 & 0.62 & 8.95 & 7.91 & 0.21 & 8.19 & 0.33 \\
\hline $\mathrm{CaO}$ & 10.24 & 0.38 & 9.80 & 10.46 & 0.04 & 10.59 & 0.36 \\
\hline $\mathrm{Na}_{2} \mathrm{O}$ & 2.27 & 0.04 & 2.23 & 2.30 & 0.01 & 2.13 & 0.16 \\
\hline $\mathrm{K}_{2} \mathrm{O}$ & 0.48 & 0.05 & 0.42 & 0.51 & 0.01 & 0.47 & 0.09 \\
\hline $\mathrm{P}_{2} \mathrm{O}_{5}$ & 0.19 & 0.01 & 0.18 & 0.20 & 0.01 & 0.20 & 0.03 \\
\hline $\mathrm{ppm}$ & & & & & & & \\
\hline $\mathrm{Sr}$ & 270.5 & 7.8 & 262.1 & 274.7 & 4.0 & 254.3 & 11.2 \\
\hline $\mathrm{Ba}$ & 93.5 & 13.2 & 78.3 & 101.1 & 1.4 & 94.6 & 19.6 \\
\hline Co & 32.9 & 1.7 & 34.7 & 32.0 & 0.8 & 32.8 & 2.7 \\
\hline $\mathrm{Cr}$ & 249.7 & 8.6 & 252.4 & 248.4 & 11.7 & 240.2 & 35.1 \\
\hline $\mathrm{Cu}$ & 46.3 & 3.0 & 49.4 & 44.8 & 1.8 & 42.3 & 2.8 \\
\hline $\mathrm{Ga}$ & 16.9 & 0.7 & 16.4 & 17.1 & 0.8 & 16.8 & 1.2 \\
\hline $\mathrm{Nb}$ & 3.0 & 0.1 & 3 & 3.0 & 0.1 & 3.8 & 1.1 \\
\hline $\mathrm{Ni}$ & 96.3 & 0.4 & 96.7 & 96.2 & 0.2 & 85.0 & 11.7 \\
\hline $\mathrm{Pb}$ & 3.7 & 0.5 & 4.1 & 3.5 & 0.4 & 4.0 & 0.7 \\
\hline $\mathrm{Rb}$ & 8.4 & 1.1 & 7.1 & 9.1 & 0.1 & 7.9 & 2.2 \\
\hline $\mathrm{Sc}$ & 23.5 & 3.4 & 25.5 & 22.5 & 4.0 & 26.1 & 1.9 \\
\hline Th & 3.9 & 0.6 & 4.4 & 3.6 & 0.4 & 4.3 & 0.8 \\
\hline V & 249.9 & 11.2 & 246 & 251.9 & 15.1 & 246.2 & 14.4 \\
\hline $\mathrm{Y}$ & 17.4 & 0.7 & 16.8 & 17.8 & 0.6 & 17.1 & 0.9 \\
\hline $\mathrm{Zn}$ & 59.8 & 1.8 & 58 & 60.8 & 1.1 & 60.0 & 5.2 \\
\hline $\mathrm{Zr}$ & 67.4 & 3.2 & 63.8 & 69.3 & 0.8 & 64.9 & 6.6 \\
\hline $\mathrm{La}$ & 3.6 & 2.1 & 2 & 4.4 & 2.2 & 7.7 & 1.9 \\
\hline $\mathrm{Ce}$ & 15.3 & 5.2 & 10.8 & 17.6 & 4.9 & 10.9 & 9.1 \\
\hline
\end{tabular}

Mean values are listed for the lower chilled margin, but only one analysis with an acceptable level of alteration is shown for the upper chilled margin. *, average weighted by thickness. 
mated from the chilled margin compositions with the phenocrysts subtracted, and the average An content of the plagioclase-phenocryst core $(\mathrm{An}=87.3)$. The result, according to Hamada and Fujii (2007), yields $2.3 \mathrm{wt} \%$ at $1150{ }^{\circ} \mathrm{C}\left(1.5 \mathrm{wt} \%\right.$ at $1100{ }^{\circ} \mathrm{C}$ and $3.3 \mathrm{wt} \%$ at $\left.1200{ }^{\circ} \mathrm{C}\right)$. We also performed MELTS calculations (Ghiorso and Sack, 1995) to obtain $1.2 \mathrm{wt} \% \mathrm{H}_{2} \mathrm{O}$ to stabilize plagioclase in the initial melt at $1150{ }^{\circ} \mathrm{C}$ and $0.15 \mathrm{GPa}$. Thus, we estimate the water content to be $1.2-2.3 \mathrm{wt} \%$. If the magma temperature is lower than $\sim 1150{ }^{\circ} \mathrm{C}$, the estimated maximum water content is almost comparable to the saturation limit, according to Moore et al. (1998). The absence of vesicles in the chilled margins and the pyroxene thermometry $\left(1100{ }^{\circ} \mathrm{C}\right.$ for pigeonite crystallization in the interstitial part) is consistent with the estimated temperature of the intruded magma being as high as $1150{ }^{\circ} \mathrm{C}$.

The density of the interstitial melt of the phenocrysts was calculated to be $2580 \mathrm{~kg} / \mathrm{m}^{3}$, using the method of Lange and Carmichael (1987), by assuming a temperature of $1150{ }^{\circ} \mathrm{C}\left(2630\right.$ and $2520 \mathrm{~kg} / \mathrm{m}^{3}$ for $1100{ }^{\circ} \mathrm{C}$ and 1200 ${ }^{\circ} \mathrm{C}$, respectively). The density of the intruded magma, including olivine $(\mathrm{Fo}=68)$ and plagioclase $(\mathrm{An}=87)$ phenocrysts, is also calculated to be $2630 \mathrm{~kg} / \mathrm{m}^{3}$. From the estimated initial melt composition, the viscosity of the initial magma containing $2.3 \mathrm{wt} \%$ water is calculated, according to Shaw (1972), to be $10 \mathrm{~Pa} \cdot \mathrm{s}$. The bulk viscosity is also calculated by adding phenocrysts (olivine: 5.3 vol\%, plagioclase: $1.9 \mathrm{vol} \%$ ), and is found to be $13 \mathrm{~Pa} \cdot \mathrm{s}$, according to the Einstein and Roscoe equation with Marsh's constant $\left[\eta=\eta_{0}(1-\varphi / 0.6)^{-2.5}\right]$ (Marsh, 1981).

\section{Fractionation of olivine, plagioclase, and clinopyroxene in the intrusion, based on whole-rock chemical compo- sitions}

The whole-rock variations, shown in Figures 6 and 7, are carefully examined below. The sill can be regarded as a closed system, as discussed above, which allows us to examine the differentiation processes on the basis of the vertical variations presented above. Note that the initial magma contained 5.3 vol $\%$ olivine and 1.9 vol\% plagioclase.

The $\mathrm{TiO}_{2}$ contents in the analyzed samples are positively correlated with incompatible trace elements (Ba, $\mathrm{Zr}, \mathrm{Nb}, \mathrm{Rb}$, and $\mathrm{Sr}$ ) and negatively correlated with compatible trace elements (Ni, Co, and $\mathrm{Cr}$ ) (Figs. 7 and $14 \mathrm{a}-$ 14d). The $\mathrm{CaO}-\mathrm{Al}_{2} \mathrm{O}_{3}$ plot shows that the $\mathrm{Al}_{2} \mathrm{O}_{3}$ content is almost constant with respect to $\mathrm{CaO}$, varying from 8 to 12 $\mathrm{wt} \%$ (Fig. 14e). We examined which minerals are required to produce these variations by comparing them with mineral compositions. Trace-element contents in clinopyroxene, plagioclase, olivine, and spinel are estimated by us-
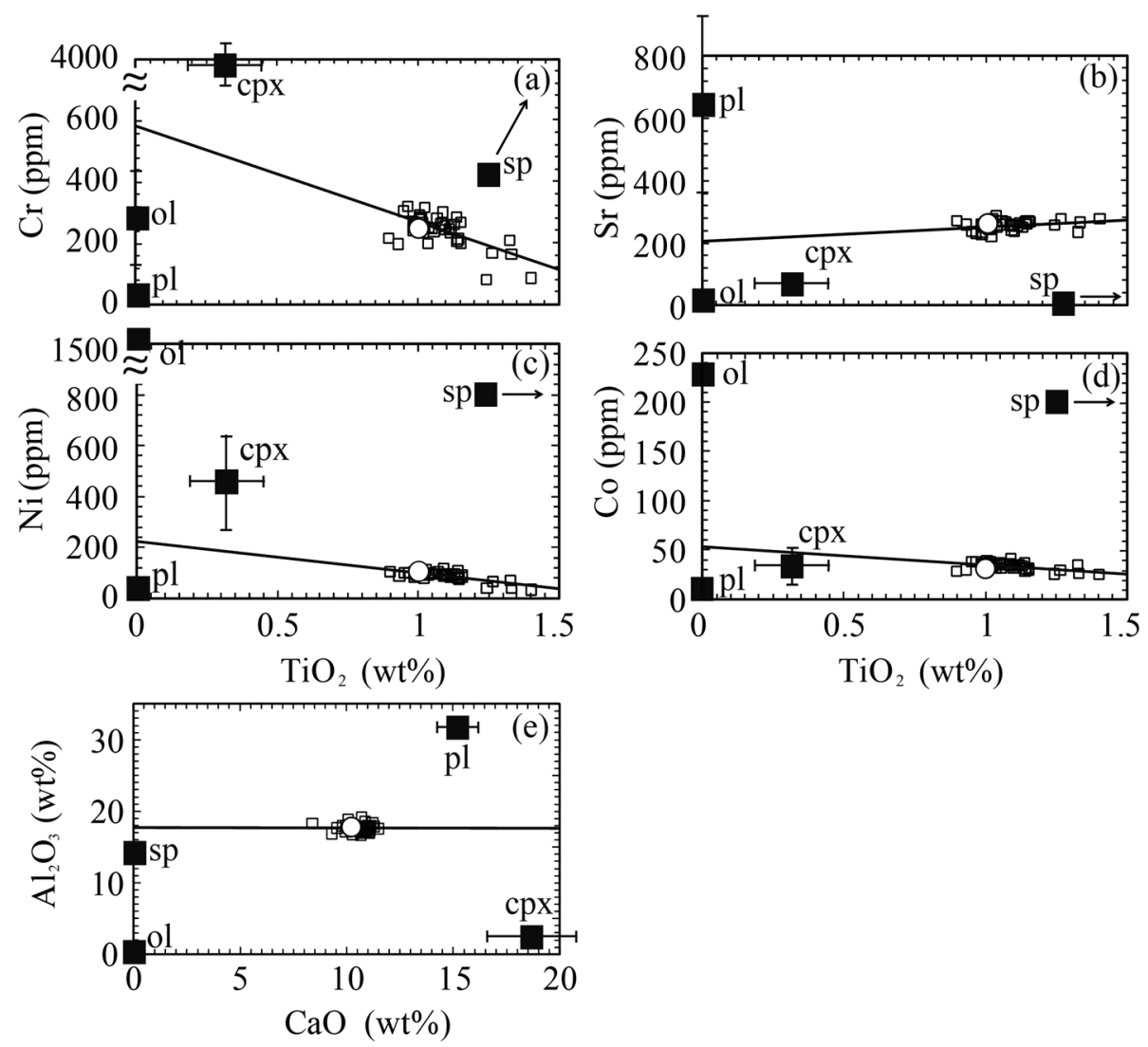

Figure 14. Trace element $(\mathrm{Cr}, \mathrm{Sr}, \mathrm{Co}$, and $\mathrm{Ni}$ ) contents plotted against the $\mathrm{TiO}_{2}$ (a)-(d) and $\mathrm{Al}_{2} \mathrm{O}_{3}$ wt $\%$ plotted against $\mathrm{CaO}$ (e). Black squares represent the compositions of olivine, plagioclase, clinopyroxene, and magnetite crystallized from the initial magma, estimated from phenocryst analyses or by using the partition coefficients listed in Table 4 for trace elements. The open circles represent the estimated bulk composition of the initial magma. The solid lines are regression lines passing through the data points. Panels (a) and (e) suggest fractionation of clinopyroxene. 
ing the above estimate of the initial melt composition and the partition coefficients listed in Table 4 (cpx, pl, ol, and sp, respectively, in Fig. 14). The reason for choosing these trace elements is their compatibility with the respective minerals. Figure 14 shows that the vectors giving rise to compositional variations cannot be reproduced simply by the separation or addition of the components olivine, plagioclase, and spinel from the initial magma (open circle in Fig. 14), but additionally require the involvement of clinopyroxene (see Figs. 14a and 14e). Therefore, we argue that not only the fractionation of olivine, plagioclase, and spinel, present as phenocrysts or their inclusions in the intruded magma, but also the fractionation of clinopyroxene is necessary to reproduce the whole-rock variations in the intrusion. This requires crystallization and fractionation of clinopyroxene after the intrusion event. From Figure 14d, we show that the negative correlation between the whole-rock $\mathrm{Co}$ and $\mathrm{TiO}_{2}$ contents can be explained by considering olivine fractionation, which is partly attributed to the settling of the olivine crystals present at the time of intrusion (Fujii, 1974b). This is suggested by the trend of increasing concentrations of $\mathrm{MgO}$, $\mathrm{FeO}, \mathrm{Ni}$, and $\mathrm{Co}$ toward the bottom of the intrusion.

\section{Local presence of pigeonite and its implication in the cooling style of the intrusion}

Pigeonite occurs only in the lower part of the Aosawa dolerite II intrusion. Fujii (1972) pointed out that pigeonite and orthopyroxene also occur only in the lower part of Aosawa dolerite I, suggesting that the occurrence of pigeonite and/or orthopyroxene is generally restricted to the lower part of the intrusion in the Aosawa dolerite. Pigeonite rims augite crystals (Fig. 3), and the rocks containing pigeonite have a higher $\mathrm{FeO}$ content and a lower $\mathrm{Mg \#}$ than the intruded magma. Therefore, the melt composition (e.g., $\mathrm{MgO}$ and $\mathrm{FeO}$ ) and temperature must be appropriate to crystallize pigeonite after a certain degree of augite crystallization. The $\mathrm{MgO}$ contents of pigeonite-saturated

Table 4. The mineral-melt partition coefficients used to calculate trace-element contents in minerals in equilibrium with the initial melt ${ }^{*}$

\begin{tabular}{lrrrcr}
\hline & \multicolumn{1}{c}{$\mathrm{Co}$} & \multicolumn{1}{c}{$\mathrm{Ni}$} & $\mathrm{Cr}$ & $\mathrm{Sr}$ & $\mathrm{Ti}$ \\
\hline Clinopyroxene & 1.2 & 4.5 & 16.3 & 0.16 & 0.33 \\
Plagioclase & 0.23 & 0.2 & 0.11 & 2.34 & 0.05 \\
Olivine & 7.24 & 16.6 & 1.13 & 0.05 & 0.04 \\
Magnetite & 4.32 & 29 & 153 & 0.11 & 7.5 \\
\hline
\end{tabular}

* See Figure 14

These partition coefficients are average values taken from GERM, partition coefficient database (Geochemical Earth Reference Model: http://earthref.org/GERM/). and augite-saturated liquids were calculated according to Sugawara (2000). At the temperature at which pigeonite and augite are in equilibrium $\left(1100{ }^{\circ} \mathrm{C}\right)$, the $\mathrm{MgO}$ contents of both pigeonite- and augite-saturated liquids are 4 $w t \%$. These values are much lower than the $\mathrm{MgO}$ content of the whole rocks $(8-9 \mathrm{wt} \%)$. Such a low MgO content, stabilizing pigeonite, can only be attained by local fractionation. The most probable situation is that slow cooling enhances the crystallization of the interstitial melt and promotes $\mathrm{Mg}$ depletion. This implies that the lower part of the intrusion (CRZ) underwent slower cooling than the upper part (PPZ). This is substantiated by the size variation of matrix plagioclase, a good indicator of the cooling rate. The plagioclase size is relatively large in the CRZ, compared to the case in the PPZ, and decreases rapidly in the lower chilled zone (Figs. 2e and 2f). The low aspect ratio of the matrix plagioclase in the $\mathrm{CRZ}$ is consistent with much slower cooling in the lower part (CRZ) than in the upper part (PPZ) (Fig. 2g).

\section{DISCUSSION}

In this chapter, we examine plausible mechanisms of fractionation in Aosawa dolerite II on the basis of the data presented thus far: the vertical variation in the whole-rock composition (Fig. 8), mineral composition (Figs. 9-11), modal abundance, grain size, aspect ratio, number density (Fig. 2), and microstructure of clinopyroxene (Figs. 12 and 13). We discuss where materials came from and were transported to, and how they were transported: via crystals settling/floatation or residual-melt migration.

\section{Crystal settling or melt migration}

All the clinopyroxene in Aosawa dolerite II crystallized after the intrusion event. Both the abundance and size of clinopyroxene are greater in the lower part than in the upper part (Fig. 2a). The sector-zoned chilled core with glass inclusions and concentrically-zoned $\mathrm{Mg}$ and $\mathrm{Cr}$-rich mantle of Cr-rich clinopyroxene (Fig. 12), which is abundant at a height of 5-15 m from the bottom, suggest that the core formed in a highly supersaturated condition, probably near the contacts, and the mantle grew at a subdued supersaturation. The localized occurrence of pigeonite only in the lower part and the increase in size and decrease in aspect ratio of matrix plagioclase, however, suggest that the lower part underwent a slower cooling than the upper part, as discussed above.

In order to reconcile these observations, which are seemingly contradictory, we propose the following scenario. Some chilled cores, which formed in the upper boundary layer, escaped and settled to concentrate in the 
lower part of the CRZ. Clinopyroxene (augite: $3,230-$ $\left.3,520 \mathrm{~kg} / \mathrm{m}^{3}\right)$ is far denser than the initial melt $(2,580 \mathrm{~kg} /$ $\mathrm{m}^{3}$, excluding phenocrysts). According to Stokes' law, the settling velocity of Cr-rich clinopyroxene crystals, $\sim 1 \mathrm{~mm}$ in size, through the initial magma is estimated to be $\sim 3.5$ $\mathrm{m} /$ day, at an assumed temperature of $1150{ }^{\circ} \mathrm{C}$. Thus, they settled from the top to the bottom of the intrusion in a month. The Cr-rich mantle then grew on the settled clinopyroxene core while passing through the center of the intrusion. The slow cooling in the lower part provided an environment for the preferential overgrowth of the clinopyroxene with a continuous supply of cores from above.

The vertical variations in the mode and number density of plagioclase phenocrysts exhibit two peaks at heights of 75-85 and 5-30 m from the bottom. The distinct concentration of plagioclase in the interval of 75-85 $\mathrm{m}$ (Fig. 2d) and the gradual increase in the grain size from the upper contact to a height of $75 \mathrm{~m}$ suggest an accumulation of plagioclase phenocrysts in this zone. The wholerock $\mathrm{Sr}$ and $\mathrm{Al}_{2} \mathrm{O}_{3}$ contents, which increase when moving from the upper contact to $75 \mathrm{~m}$ in height, are consistent with this interpretation. Such an accumulation of plagioclases is attributable either to a settling or floatation of plagioclase, which was either initially present or crystallized after the intrusion event. The An content of a plagioclase phenocryst core is $80-90$, which is slightly denser than that of the intruded interstitial magma (intruded magma: $2580 \mathrm{~kg} / \mathrm{m}^{3}$, plagioclase: 2,732-2,746 $\mathrm{kg} / \mathrm{m}^{3}$ ). The settling velocity of a plagioclase phenocryst, $\sim 1 \mathrm{~mm}$ in size, is estimated to be $0.77 \mathrm{~m} / \mathrm{d}$ at $1150{ }^{\circ} \mathrm{C}$, at which it would have taken 130 days to settle from the top to the bottom. It is well known that plagioclase settles slower than mafic minerals, not only because of the lower density, but also because of its tabular morphology (Kerr and Lister, 1991). It is inferred that the two peaks in the plagioclase mode are attributed to the settling of plagioclase with a very slow rate. This is also consistent with the preferential nucleation and growth of plagioclase (and clinopyroxene) in the upper boundary layer.

The high concentration of plagioclase phenocrysts in the plagioclase-phyric zone is due to the capture by rapid advancement of the upper crystallization front (Simura and Ozawa, 2006). The high concentration may have been helped by the floatation of plagioclase driven by a counter flow from the settling of blocks of the host sedimentary rock. Contrary to this, the minor diffuse concentrations of plagioclase in the interval of 5-30 m may be attributed to an accumulation of plagioclase crystals that crystallized before the intrusion, and those escaped capture in the upper zone. Moving downwards through the plagioclasephyric zone, an increase in $\mathrm{Ti}, \mathrm{Nb}$, and $\mathrm{Zr}$ is also noted, which is attributed to the downward increase in the mag- netite mode. Magnetite is much heavier than olivine and clinopyroxene, but the grain size is $0.01-0.1 \mathrm{~mm}$, which corresponds to a settling velocity $(<0.042 \mathrm{~m} / \mathrm{d})$ smaller than that of plagioclase.

At heights of 75-85 m from the bottom (Fig. 8), in the zone enriched in incompatible elements and depleted in compatible elements, the settling of clinopyroxene, as well as of olivine, from the upper boundary layer contributed to its fractionation. The zone with higher concentrations of compatible elements and lower concentrations of incompatible elements, at 5-20 m from the bottom, is also partly attributed to the settling of mafic phenocrysts. The weak but consistent enrichment of incompatible elements, and the depletion of compatible elements at 20-40 m from the bottom, however, cannot be explained by crystal settling. This requires other fractionation mechanisms to be considered, which will be discussed below.

\section{Upwelling of residual melts}

The rim of clinopyroxene above the zone of high concentration of Cr-rich clinopyroxene, at a height of 20-40 m, and near the upper contact, at a height of 90-95 m, is notably rich in $\mathrm{TiO}_{2}$ and $\mathrm{MnO}$ and low in $\mathrm{Mg} \#$ (Fig. 10). These two horizons are also two of the zones where whole-rock incompatible elements are more abundant and compatible elements less abundant than in any other horizons (Fig. 8).

Since Cr-rich and $\mathrm{Cr}$-poor clinopyroxene crystals are more abundant in the lower part of the clinopyroxenerich zone, it is expected that $\mathrm{Cr}$-poor clinopyroxene overgrew on the Cr-rich cores to enhance the enrichment of clinopyroxene in this zone, causing fractionation of the interstitial melt. This interstitial melt is rich in $\mathrm{SiO}_{2}$, but slightly low in $\mathrm{FeO}$, as suggested from the whole-rock variation shown in Figure 6. Therefore, this melt is lighter than the initial melt and buoyant enough to induce compositional convection. Its transportation up to the plagioclase-phyric zone without significant interaction with the surrounding melt might have contributed somewhat to the fractionation of the upper part (75-85 $\mathrm{m}$ from the bottom). The high concentration of incompatible elements just above the zone containing abundant $\mathrm{Cr}$-rich clinopyroxene can be explained by the transportation of the fractionated melt formed in the bottom of the clinopyroxene-rich zone and its entrapment due to the advancement of the lower crystallization front.

The whole-rock composition was similar to the composition of the intruded magma at $\sim 60 \mathrm{~m}$ in height (top of the clinopyroxene-rich zone), and the compositional ranges of clinopyroxene and plagioclase are the smallest there (Fig. 9 for clinopyroxene). The homogeneity implies 
a prolonged period at high temperature at this height, which is slightly above the middle of the sill. The similarity of the whole-rock composition at the horizon to the initial magma indicates that the center of the intrusion is basically unaffected by the fractionation occurring in the intrusion. The top of the clinopyroxene-rich zone was kept at high temperatures, not allowing further crystal fractionation. Clinopyroxene (and olivine) passed through this zone in a short time ( $<$ a few months) without significant interaction with the interstitial melt. This is also true for the possible transportation of the fractionated melt from the lower boundary layer to the upper boundary layer.

The fractionation mechanism of Aosawa dolerite II is a sort of boundary-layer fractionation through a combination of the settling of crystals formed in the upper boundary layer and of compositional convection from the lower boundary layer (Fig. 15). Separation of the fractionated interstitial melt from the lower boundary layer may have become effective due to the formation of an accumulation zone (crystal fraction $=\sim 0.25$ ) as a result of settling from the upper boundary layer. We infer that boundary-layer fractionation proceeded through a coupling of the formation and ascent of a fractionated melt in the bottom boundary layer and the progressive fractionation of the overlying melt layer, with a limited thickness of 20-30 $\mathrm{m}$, and its feeding to the underlying boundary layer.

In order to explain all these fractionation mechanisms, the sill must be stagnant. Therefore, we argue that heat in the sill was basically transported through heat conduction but not thermal convection. The effective heat loss from the top of the intrusion is attributed to a hydrothermal system above the intrusion (Morton and Sleep, 1985). The reason why the final solidification site is located at two thirds of the way from the bottom, in spite of a faster cooling of the upper part than the lower part, may be either due to (1) subdued hydrothermal activities in a later stage of the solidification or, (2) suppression of the advancement of the upper boundary layer during the earlier stage of compositional convection, which is caused by the transportation of the fractionated melt from the lower boundary layer, or both. The fractionated melt, which formed in the lower boundary layer, rose through the overlying melt layer, as distinct plumes and without interaction with the central melt, to maintain the initial magma composition at a height of $\sim 60 \mathrm{~m}$ from the bottom (Simura and Ozawa, 2011). The acceleration of the inward advancement of the lower boundary layer in the later stage, relative to the ascent of the compositional plumes, caused fractionation in the zone $20-30 \mathrm{~m}$ from the bottom.

\section{CONCLUSIONS}

1. The initial magma of Aosawa dolerite II contained olivine $(5.3 \mathrm{vol} \%)$ and plagioclase (1.9 vol\%) phenocrysts, but did not have clinopyroxene as a phenocryst. The composition of the initial magma was estimated from samples from the upper and lower chilled margins, which are similar in whole-rock chemical compositions. The estimated composition is comparable to the average composition of the intrusion, indicating that a single intrusion pulse or

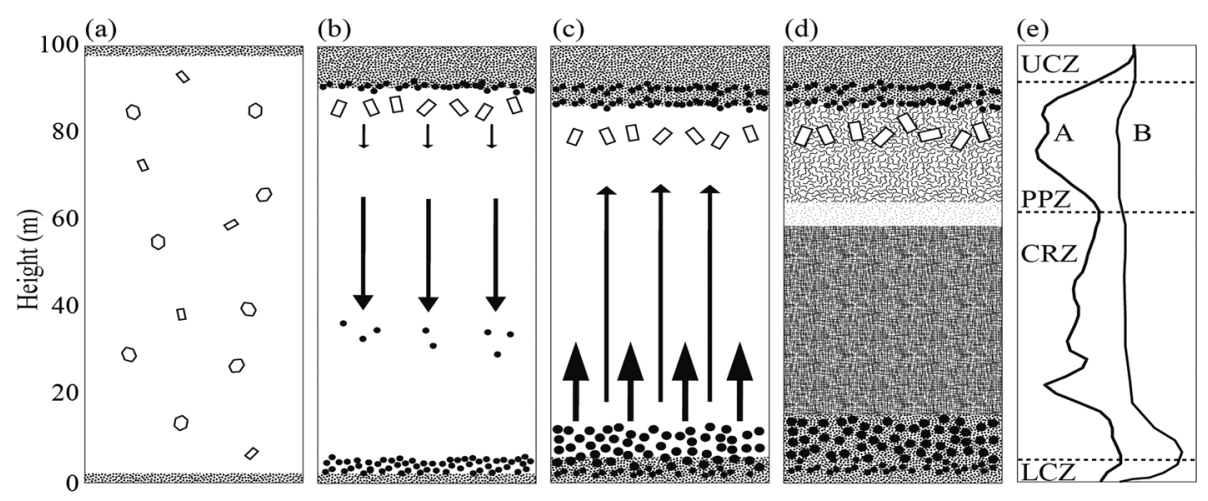

Figure 15. Schematic illustrations of the fractionation processes in Aosawa dolerite II. (a) Intrusion of magma laden with olivine and plagioclase into the host black mudstone forming a coherent sill $100 \mathrm{~m}$ thick, and the formation of chilled margins. (b) Preferential nucleation and growth of a core $\mathrm{Cr}$-rich clinopyroxene in the upper boundary layers due to effective cooling from above and its settling from the unstable boundary layer. Plagioclase also settled, but very slowly. (c) Enhanced growth of clinopyroxene (olivine and plagioclase) on the settled core in the lower boundary layer to produce a fractionated melt, which was transported upwards due to its buoyancy (compositional convection). A significant fraction of the plagioclase phenocrysts was captured by the descending upper boundary layer to form the PPZ. (d) Solidification of the central part without significant modification by the fractionation shown in (b) and (c). (e) The observed vertical variation of the wholerock $\mathrm{Cr}$ content (A), and the mode of Cr-rich clinopyroxene (B). Upward arrows indicate transportation of the residual melt, and downward arrows indicate the settling of Cr-rich clinopyroxene. To simplify the diagrams of (b), (c) and (d), olivine and plagioclase are not shown, except for plagioclase phenocrysts near the roof. See Figure 5 for definition and abbreviations of four lithological zones. 
several successive pulses of a homogeneous magma formed Aosawa dolerite II.

2. Systematic stratigraphic variations in the wholerock composition can be identified after subtracting localscale variations. The stratigraphic variations are characterized by two zones rich in incompatible elements and poor in compatible elements near the roof (at 75-85 $\mathrm{m}$ in height) and near the bottom (at $20-40 \mathrm{~m}$ in height) of the intrusion.

3. The $\mathrm{TiO}_{2}$ content shows good correlation with other incompatible trace elements and compatible trace elements. The observed correlation and the lack of change in $\mathrm{Al}_{2} \mathrm{O}_{3}$ content with variations in the $\mathrm{CaO}$ content are explained not only by the transfer of the components of olivine and plagioclase present as phenocrysts in the initial magma but also by the transfer of the clinopyroxene components. Thus, the sill-scale fractionation must have been accompanied by in-situ crystallization of clinopyroxene (+ olivine and plagioclase).

4. Moving downwards, the grain size and modal abundance of clinopyroxene increases. The $\mathrm{Cr}_{2} \mathrm{O}_{3}$ content in the clinopyroxene core shows a bimodal distribution at $0.1-0.3 \mathrm{wt} \%$ and $0.6-0.8 \mathrm{wt} \%$ in the whole sill, as well as in a single sample. The modal percentage of $\mathrm{Cr}$-rich clinopyroxene increases downwards and is highly concentrated in the height range of 5-15 m from the lower contact. The $\mathrm{Cr}$-rich clinopyroxene has a core with several features, such as sector zoning and glass inclusions, which suggest rapid growth. These features suggest that clinopyroxene crystallized in the upper boundary layer, where cooling was more effective, and then settled to concentrate near the bottom. The increase in size and aspect ratio of matrix plagioclase support the faster cooling in the upper part.

5. The extreme heterogeneity of clinopyroxene, enrichment of $\mathrm{Mn}$ and $\mathrm{TiO}_{2}$, and low $\mathrm{Mg} \#$ at the rim of clinopyroxene (at 20-40 $\mathrm{m}$ in height) above the zone containing abundant $\mathrm{Cr}$-rich clinopyroxene (5-15 m), all suggest the formation of a fractionated melt in the clinopyroxene-rich zone and its upward transportation.

6. The occurrence of the two fractionated zone near the top and bottom of the sill can be explained by the combination of (1) settling of clinopyroxene (+ olivine and plagioclase) formed in the upper boundary layer to the bottom of the sill and (2) enhanced overgrowth on accumulated crystals to produce a light fractionated melt. The settling of mafic minerals caused the fractionation of the upper boundary layer but reduced the concentration of incompatible elements in the lower boundary layer. The fractionated melt was transported upward to further deplete the lower part and possibly to enhance the fractionation of the upper boundary layer.
7. Aosawa dolerite II underwent in-situ differentiation via a boundary-layer fractionation mechanism through the settling of mafic minerals formed in the upper boundary layer to accumulate in the lower boundary layer, inducing compositional convection. This fractionation mechanism may have been caused by efficient heat loss from the roof and an unstable upper boundary layer that allowed the separation of crystals.

\section{ACKNOWLEDGMENTS}

We thank Toshitsugu Fujii, Hiroko Nagahara, Hikaru Iwamori, Takeyoshi Yoshida, and Hiroaki Sato for their valuable discussions. Thanks are also due to Tetsuya Sakuyama, Jun Sasaki, and Kenta Ueki for discussions and encouragement. We are thankful to Hideto Yoshida for the EPMA and XRF analyses. Reviews by H. Sato and S. Umino were very helpful to revise the manuscript. We also thank M. Obata for handling the manuscript and suggestions to improve the manuscript.

\section{SUPPLEMENTARY MATERIAL}

Color version of Figures 3, 5, and 12 is available online from http://joi.jlc.jst.go.jp/JST.JSTAGE/jmps/100306.

\section{REFERENCES}

Amano, K. and Sato, H. (1989) Neogene tectonics of the central part of Northeast Honshu Arc. The memoirs of the Geological Society of Japan, 32, 81-96 (in Japanese with English abstract).

Anderson, D.H. and Hawkes, H.E. (1958) Relative mobility of the common elements in weathering of some schist and granite areas. Geochimica et Cosmochimica Acta, 14, 204-210.

Bence, A.E. and Albee A.L. (1968) Empirical correction factors for the electron microanalysis of silicates and oxide. Journal of Geology, 76, 382-403.

Fujii, T. (1972) Petrology of the Aosawa dolerite sill, North-eastern Japan. pp.168, Master Thesis, Geological Institute, University of Tokyo.

Fujii, T. (1974a) Petrology of the Aosawa dolerite sill, Japan. Journal of the Faculty of Science, The University of Tokyo, 19, 57-80.

Fujii, T. (1974b) Crystal settling in a sill. Lithos, 7, 133-137.

Ghiorso, M.S. and Sack, R.O. (1995) Chemical mass-transfer in magmatic processes 4 . A revised and internally consistent thermodynamic model for the interpolation and extrapolation of liquid-solid equilibria in magmatic systems at elevated temperatures and pressures. Contributions to Mineralogy and Petrology, 119, 197-212.

Hamada, M. and Fujii, T. (2007) $\mathrm{H}_{2} \mathrm{O}$-rich island arc low-K tholeiite magma inferred from Ca-rich plagioclase-melt inclusion equilibria. Geochemical Journal, 41, 437-461.

Haslinger, F., Thurber, C., Mandernach, M. and Okubo, P. (2001) Tomographic image of P-velocity structure beneath Kilauea's East Rift Zone and South Frank: seismic evidence for a deep 
magma body. Geophysical Research Letters, 28, 375-378.

Holm, D.D. (1954) Estimating porosity of sedimentary rocks from bulk density. Journal of Geology, 62, 102-107.

Irvine, T.N. (1982) Terminology for layered intrusions. Journal of Petrology, 23, 127-162.

Jaupart, C. and Tait, S. (1995) Dynamics of differentiation in magma reservoirs. Journal of Geophysical Research, 100, 17, 615-17, 636.

Jellinek, A.M. and Kerr, R.C. (2001) Magma dynamics, crystallization, and chemical differentiation of the 1959 Kilauea Iki lava lake, Hawaii, revisited. Journal of Volcanology and Geothermal Research, 110, 235-263.

Kerr, R.C and Tait, S.R. (1986) Crystallization and compositional convection in a porous medium with application to layered igneous intrusion. Journal of Geophysical Research, 91, 3591-3608.

Kerr, R.C. and Lister, J.R. (1991) The effect of shape on crystal settling and on the rheology. Journal of Geology, 99, 457467.

Kuritani, T., Yokoyama, T. and Nakamura, E. (2007) Rates of thermal and chemical evolution of magmas in a cooling magma chamber: a chronological and theoretical study on basaltic and andesitic lavas from Rishiri Volcano, Japan. Journal of Petrology, 48, 1295-1319.

Kuritani, T. (2009) The relative roles of boundary layer fractionation and homogeneous fractionation in cooling basaltic magma chambers. Lithos, 110, 247-261.

Kushiro, I. (1994) Analyses of major and minor elements in silicate rocks with X-ray fluorescence, in Evolution of the Crust in Island Arcs. 1-22, Grant Report for the Ministry of Education of Japan.

Lange, R.A. and Carmichael, I.S.E. (1987) Density of $\mathrm{Na}_{2} \mathrm{O}-\mathrm{K}_{2} \mathrm{O}$ - $\mathrm{CaO}-\mathrm{MgO}-\mathrm{FeO}-\mathrm{Fe}_{2} \mathrm{O}_{3}-\mathrm{Al}_{2} \mathrm{O}_{3}-\mathrm{TiO}_{2}-\mathrm{SiO}_{2}$ liquids new measurements and derived partial molar properties. Geochimica et Cosmochimica Acta, 51, 2931-2946.

Lee, J.M. and Ukawa, M. (1992) The South Fossa, Magna, Japan, revealed by high-resolution $\mathrm{P}$-and $\mathrm{S}$-wave travel time tomography. Tectonophysics, 207, 377-396.

Lindsley, D.H. (1983) Pyroxene thermometry. American Mineralogist, 68, 477-493.

Marsh, B.D. (1981) On the crystallinity, probability of occurrence, and rheology of lava and magma. Contributions to Mineralogy and Petrology, 78, 85-98.

Marsh, B.D. (1996) Solidification fronts and magmatic evolution. Mineralogical Magazine, 60, 5-40.

Moore, G., Vennemann, T. and Carmichael, I.S.E. (1998) An empirical model for the solubility of $\mathrm{H} 2 \mathrm{O}$ in magmas to 3kilobars. American Mineralogist, 83, 36-42.

Morton, J.L. and Sleep, N.H. (1985) A mid-ocean ridge thermal model: constraints on the volume of axial hydrothermal heat flux. Journal of Geophysical Research, 90, 11345-11353.
Nakamura, Y. and Kushiro, I. (1970) Equilibrium relations of hypersthene, pigeonite and augite in crystallizing magma; microprobe study of a pigeonite andesite from Weiselberg. American Mineralogist, 55, 1999-2015.

Ohki, J., Shuto, K. and Itaya, T. (1995) K-Ar ages of volcanic rocks in the Miocene Aosawa Formation occurring in the Dewa Hill, Northeast Japan arc. The Memoirs of the Geological Society of Japan, 44, 55-63 (in Japanese with English abstract).

Sato, H. (1986) Geologic Development of the Cenozoic System in Central Northeast Honshu (Between Sakata and Furukawa). Journal of the Faculty of Science, Tohoku University, 1-45. (in Japanese with English abstract)

Scoon, R.N. and Michell, A.A. (1994) Discordant Iron-rich ultramafic pegmatites in the Bushveld Complex and their Relationship to Iron-rich intercumulus and residual liquidus. Journal of Petrology, 35, 881-917.

Shaw, H.R. (1972) Viscosities of magmatic silicate liquids: an empirical method of prediction. American Journal of Science, 272, 870-893.

Simura, R. and Ozawa, K. (2006) Mechanism of Crystal Redistribution in a Sheet-like Magma Body: Constraints from the Nosappumisaki and Other Shoshonite Intrusions in the Nemuro Peninsula, Notheren Japan. Journal of Petrology, 47, 1809-1851.

Simura, R. and Ozawa, K. (2011) Magmatic fractionation by compositional convection in a sheet-like magma body: constrains from the Nosappumisaki intrusion, Northern Japan. Journal of Petrology, 52, 1887-1925.

Sinton, J. and Detrick, R. (1992) Mid-Ocean Ridge Magma Chamber. Journal of Geophysical Research, 97, 197-216.

Sugawara, T. (2000) Empirical relationships between temperature, pressure, and $\mathrm{MgO}$ content in olivine and pyroxene saturated liquid. Journal of Geophysical Research, 105, 8457-8472.

Tait, S. and Jaupart, C. (1992) Compositional convection in a reactive crystalline mush and melt differentiation. Journal of Geophysical Research, 97, 6735-6756.

Tsuchiya, N. (1989a) Submarine basalt volcanism of Miocene Aosawa Formation in the Akita-Yamagata oil field basin, backarc region of Northeast Japan. The memoirs of the Geological Society of Japan, 32, 399-408 (in Japanese with English abstract)

Tsuchiya, N. (1989b) Geology of the Osawa district. With geological sheet map at 1:50,000, pp. 85, Geological Survey of Japan (in Japanese with English abstract 6p).

Manuscript received March 6, 2010

Manuscript accepted September 23, 20011

Manuscript handled by Masaaki Obata 